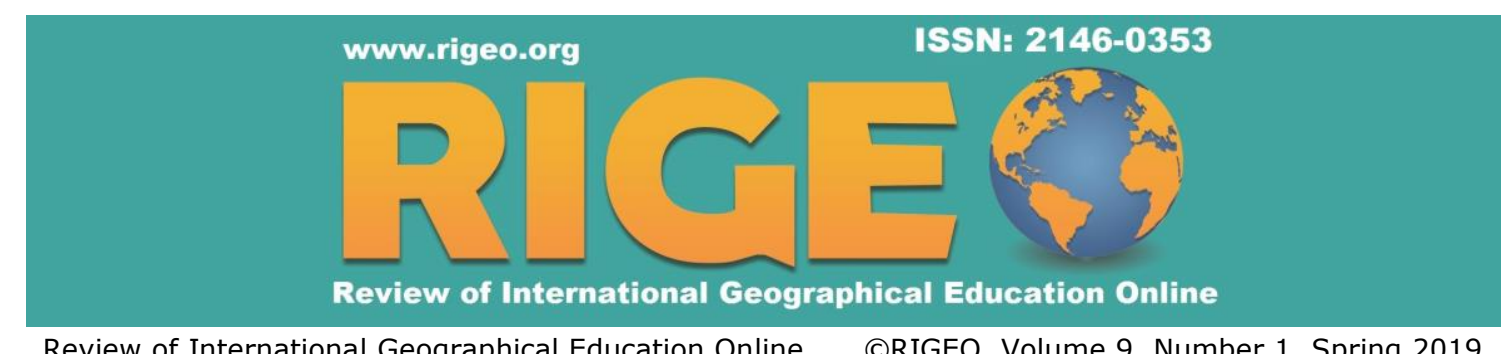

Review of International Geographical Education Online CRIGEO, Volume 9, Number 1, Spring 2019

Research Article

Copyright $\odot$ RIGEO 2019

To cite this article: Akbaş, Y.; Şahin, İ. F..; Meral, E. (2019). Implementing Argumentation-Based Science Learning Approach in Social Studies: Academic Achievement and Students' Views. Review of International Geographical Education Online (RIGEO), 9(1), 209-245, Retrieved from http://www.rigeo.org/vol9no1/Number1Spring/RIGEO-V9-N1-10.pdf DOI: $10.33403 /$ rigeo.529139

Submitted: February 1, 2019

Revised: March 12, 2019

Accepted: March 30, 2019

\title{
Implementing Argumentation-Based Science Learning Approach in Social Studies: Academic Achievement and Students' Views*
}

\author{
Yavuz AKBAŞ ${ }^{1}$ \\ Trabzon University, Trabzon, TURKEY \\ İbrahim Fevzi ŞAHİN² \\ Atatürk University, Erzurum, TURKEY \\ Elif MERAL ${ }^{3}$ \\ Atatürk University, Erzurum, TURKEY
}

\begin{abstract}
The purpose of this study was to investigate the effects of the argumentation-based science learning approach on students' academic achievements and examine student views about use of this approach in social studies. We used a mixed methods research design to document changes as a result of an argumentation-based science learning approach implementation. The participants were 94 seventh grade students from three different classrooms of a middle school in Erzurum, Turkey. We developed the Population in our Country Academic Achievement Test to collect quantitative data before and after the implementation, and used a semi-structured interview form to collect quantitative data after the implementation. Using descriptive, one-way ANOVA, and multiple comparison Tukey test statistical data analysis methods, we analyzed the quantitative data. Then, we used content analysis method to analyze the qualitative data. Results of the quantitative data analysis showed that there was no statistically significant difference between academic achievements mean scores of the students in the experimental and control groups in the pre-test. However, after the implementation, there were statistically significant differences between groups indicating that academic achievement mean scores
\end{abstract}

*This study was generated from doctoral thesis entitled "The Effects of the Argumentation-Based Science Learning Approach on Students' Academic Achievement, Critical Thinking Dispositions and Argumentation Development Skills"

${ }^{1}$ Associate Professor, Department of Turkish and Social Sciences Education, Trabzon University, Trabzon, Turkey, yavuzakbas52 [at] gmail.com. ORCID:0000-0002-3500-4701

2Professor, Department of Turkish and Social Sciences Education, Atatürk University, Erzurum, Turkey, ifevzi [at] atauni.edu.tr. ORCID:0000-0003-2566-4623

${ }^{3}$ Corresponding author: Associate Professor, Department of Turkish and Social Sciences Education, Atatürk University, Erzurum, Turkey, elif.meral [at] atauni.edu.tr. ORCID:0000-0002-2560-0120

(C) Review of International Geographical Education Online

RIGEO 2019

ISSN: $2146-0353$

www.rigeo.org 
of students in the experimental group was statistically higher than those students in the control groups in the post-test. Results of the qualitative data analysis indicated the argumentation-based science learning approach activities helped students understand subjects better, facilitated their learning, provided permanent learning opportunities, increased their interest and attitudes towards the course, and enhanced their success in social studies. These results suggested that implementing the argumentation-based science learning approach in social studies was effective in enhancing students' academic achievement and resulted in developing positive views of students about the approach.

\section{Keywords}

Argumentation-Based Science Learning; Argumentation; Social Studies; Mixed Methods; Academic Achievement; Students' Views

Developments in the information age have required individuals responsible for "knowing" to have many necessary skills such as thinking, questioning, researching, and making fast and effective decisions. (Alkın-Şahin, Tunca \& Ulubey, 2014). The fact that individuals who are responsible for "knowing" and possessing these necessary skills can be possible by realizing the significance of "why" and "how" questions. Individuals spending more time with information and communication technologies can spend less time on why and how type of questions that require reasoning because they reach the information quickly and accept the information without questioning. Thus, individuals may have difficulties in constructing the information in the learning process without questioning since they reach the information quickly (Türkoguz \& Cin, 2013). In this context, new approaches in education emphasize that learning environments should be designed more flexible and students should be active in the learning process. Thus, there is a need for new inquiry-based learning environments that enable learners to become high-level thinking individuals who conduct research, ask questions, and use technology as active recipients of information (Tezci \& Perkmen, 2013). Researchers indicate that Argumentation Based Science Learning (ABSL) approach is one of the approaches providing these environments to learners (Antiliou, 2012; Chin \& Osborne, 2008; Driver, Newton \& Osborne, 2000; Hohenshell \& Hand, 2006; JimenezAleixandre \& Erduran, 2007; Jimenez-Aleixandre Rodriguez, \& Duschl, 2000; Nusbaum, 2008; Sampson \& Gleim, 2009; Şekerci, 2013; Şahin, 2016).

The ABSL is a learning approach that aims to cultivate students as individuals who have strong social skills, develop collaboration and communication skills, are openminded, can conduct research, ask questions, collect and share information, and critically evaluate arguments and justifications in discussions (Güler, 2016). The ABSL approach consists of a structure that strengthens students' reasoning during their work in scientific activities and provides high-level cognitive support (Yore, 2000). This structure (a) helps students formulate questions, (b) practice, claim and provide evidence for these claims, and (c) create arguments with effective reasoning (Keys, Hand, Prain \& Collins, 1999). During the argumentation process, students can improve their conceptual understanding (Cavlazoglu \& Stuessy, 2017) by comparing different theories via use of existing data to support or reject theories. This is because students choose the most appropriate theory among different theories in the argumentation process and this process provides a better conceptual understanding of targeted subjects (Lawson, 2003). The process of argumentation assists students in evaluating new 
knowledge, conceptualizing the knowledge in students' individual mental structures, and learning conceptual knowledge in a manner consistent with scientific knowledge (Bell \& Linn, 2000; Dawson \& Venville, 2009; Zohar \& Nemet, 2002). Argumentation activities individually or in groups requiring students to think and actively participate in the learning process provides social activity environments for students (Driver, Newton \& Osborne, 2000). Students in argumentation-based learning environments can construct their knowledge actively and socially. In these learning environments, since students can express their ideas clearly, the argumentation approach can be used for evaluation and self-assessment (Bell \& Linn, 2000; Tekeli, 2009). With the ABSL approach, students can use different strategies including asking questions, creating claims, testing claims, creating new claims, and comparing their claims with existing scientific information (Hand, Wallace \& Yang, 2004).

In the related literature, researchers stated that learning environments designed with ABSL approach have positive effects on students' (a) high-level thinking skills (Antiliou, 2012, Kunsch, Schnarr \& van Tyle, 2014; Lawson, 2003; Nussbaum \& Sinatra, 2003; Nussbaum, Winsor, Aqui \& Polyquin, 2007; von Aufschnaiter, Erduran, Osborne \& Simon, 2008), (b) argument creating skills (Çetin, Kutluca \& Kaya, 2013; Çiftçi, 2016; Jan, 2009; Lu \& Zhang, 2013; Knight \& McNeill, 2015; Öztürk, 2013; Untereiner, 2013), (c) understanding of nature of science (Çetin, Erduran \& Kaya, 2010; Driver, Newton \& Osborne, 2000; Kutluca, 2016; Osborne, Erduran \& Simon, 2004; Tümay \& Köseoğlu, 2010), (d) meaningful understanding of concepts (Basso, 2009; Boyraz, Hacığlu \& Aygün, 2016; Cavlazoglu \& Stuessy, 2017; Ortega, Alzate \& Bargallo, 2015; Türkoguz \& Cin, 2013; Ulu \& Bayram, 2015; Weng, Lin \& She, 2017), and (e) academic achievement (Greenbowe, Poock, Burke \& Hand, 2007; Güler, 2016; Öğreten, 2014; Uluay, 2012).

The ABSL approach helps individuals express their ideas about a subject and see their missing points (Akpınar \& Ergin, 2005; Duran, Doruk \& Kaplan, 2017). In addition, individuals can gain questioning and research skills as they behave like a scientist in the argumentation process (Driver, Newton \& Osborne, 2000). In learning environments, the argumentation process enabling students to be curious and active has important roles in student learning with questioning a topic and developing conceptual understanding as well as learning the students' thinking and reasoning process (Chin \& Osborne, 2010; Hasançebi, 2014; Kaya \& Kılıç 2008).

According to the international literature on argumentation, although there are many benefits of using the ABSL approach in learning environments, the use of this approach has been mostly in the field of science education (Albe, 2007; Cavlazoglu \& Stuessy, 2018; Chin \& Osborne, 2010; Crowell \& Kuhn, 2012; Duschl \& Osborne, 2002; Erduran, Simon \& Osborne, 2004; Kolsto, 2006; Kuhn, Wang \& Li 2010; Sadler \& Fowler, 2006; Tippett, 2009; Zohar \& Nemet, 2002), and limited in the social sciences (Larson, Britt \& Kurby, 2009; Mirza \& Perret-Clermont, 2009; Monte-Sano, 2012; Nussbaum, 2002; Nussbaum, 2008; Swartz, 2008; Wissinger, 2012) has started to be used in social sciences in the recent years. 
Literature at the national level about the use of the ABSL approach, as similar at the international level, indicate that this approach has been widely used in science education (Çinici, Özden, Herdem, Karabiber \& Deniz, 2014; Demirel, 2016; Namdar \& Tuskan, 2018; Okumuş \& Ünal, 2012; Özcan, Aktamış \& Hiğde, 2018; Uluçınar-Sağır \& Kılıç, 2013), but it is noteworthy that there has been a limited number of studies in the field of social studies education (Demir, 2017; Torun, 2015).

Nussbaum (2002) stated that social studies curriculum provides many opportunities for students to study and practice argumentation in social studies education. He emphasized that students can create arguments about reasons for social events, political and social practices (e.g., democracy and imperialism), and contemporary issues (e.g., migration). He also suggested that students' interest in social studies curriculum should be increased in order to increase their capacity to participate in the argumentation and justification processes. In a research study, Oğuz-Haçat and Demir (2016) demonstrated the suitability of the ABSL approach for teaching subjects in social studies courses. In this context, we claimed that implementation of the ABSL approach can have positive effects on the academic achievement of students in social studies. In this vein, the problem statements of this research were defined as "Were there any significant effect of the ABSL approach on the academic achievements of students in the seventh-grade social studies courses?" and "What were the views of the students about the social studies course prepared with the ABSL approach?" We identified that in the literature there was no research study examining the effects of the ABSL approach on seventhgrade students' academic achievements in the social studies courses by using various activities with ABSL approach in the classroom. Additionally, none of the previous studies used mixed methods research design in implementing the ABSL approach in social studies research literature. In this study, to address the gaps in the literature, we used a mixed methods design to document the effects of the ABSL approach on students' academic achievements and student views about use of this approach in social studies courses.

\section{Methodology}

\section{Research Design}

In this study, we a used mixed methods approach. Mixed methods approach is a research methodology in which both quantitative and qualitative research methods are used together (Fraenkel, Wallen \& Hyun, 2012). This methodology allows a better understanding of the research problems by using a combination of quantitative and qualitative research methods (Creswell, 2012). In the literature, researchers have classified mixed methods research designs differently. According to Creswell and Plano-Clark (2007), there are four types of mixed methods research designs: triangulation design, embedded design, explanatory design, and exploratory design. In this study, since we used predominantly quantitative data and qualitative data to support the quantitative data, we employed embedded design (see Figure 1). 


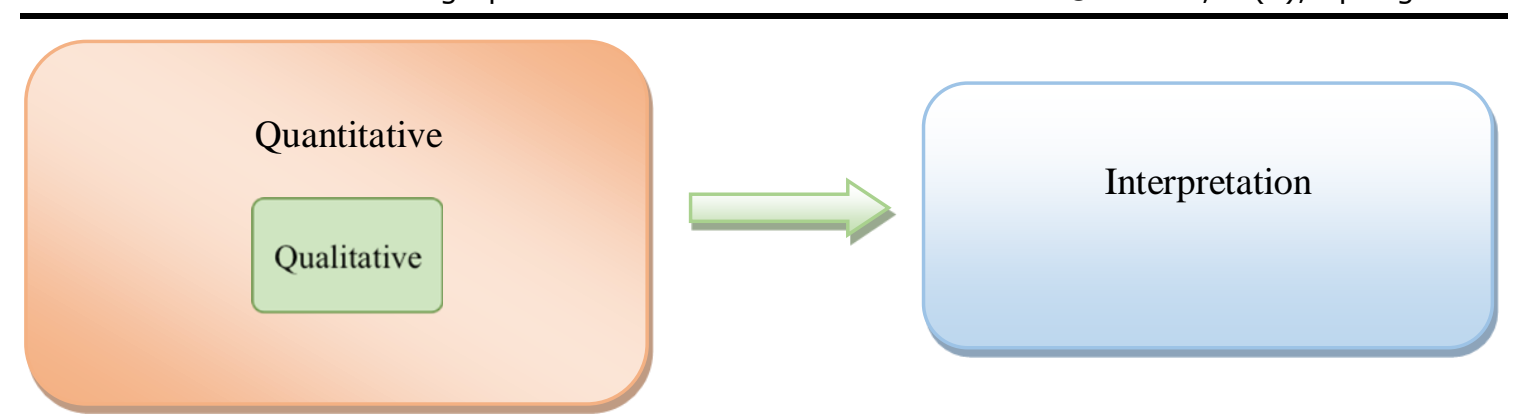

Figure 1. Embedded research design (Creswell \& Plano-Clark, 2007)

In the quantitative part of this study, a quasi-experimental design with pretestposttest equivalent control groups was used. The most important feature of the experimental design is that the independent variable can be manipulated (Fraenkel, Wallen \& Hyun, 2012; McMillan \& Schumaher, 2014). In this study, no random assignment was done to determine the experimental and control groups since only available groups were used. The experimental and control groups were randomly assigned among available groups. Before assigning experimental and control groups, academic achievement pre-tests scores of the groups were controlled to make sure that the groups were equivalent. In the qualitative part of the study, semi-structured interviews with the students in the experimental group were conducted in order to support the quantitative data with qualitative data.

\section{Participants}

The participants of this study were 94 seventh grade students from three different classrooms of a middle school in 2017 Fall and 2018 Spring semesters in Erzurum, Turkey. One of the classrooms was assigned as experimental group (EG; $n=33$ ) in which the ABSL approach was implemented, and the other two classrooms were assigned as control groups. First control group was defined as CG1 $(n=30)$ and second control group was defined as CG2 $(n=31)$. Table 1 shows the demographic information of the participants in this study.

Table 1

Participants' Demographic Information

\begin{tabular}{llcc}
\hline Groups & Gender & Frequency & Percentage \\
\hline EG & Male & 18 & 38.3 \\
& Female & 15 & 31.9 \\
CG1 & Male & 18 & 38.3 \\
& Female & 12 & 25.5 \\
CG2 & Male & 11 & 23.4 \\
& Female & 20 & 42.6 \\
\hline Total & & 94 & 100 \\
\hline
\end{tabular}

For the qualitative part of the study, semi-structured interviews were conducted with 10 students selected from the EG. One of the purposive sampling methods, maximum variation purposive sampling method was used to identify students for semi-structured 
interviews. In the identification of the students to be interviewed, maximum variation was obtained by taking into account students' genders, achievement levels in the pre-test scores (high, medium, and low), and grade averages (i.e., GPA) in the previous year's social studies course.

Examining the equivalence of experimental and control groups. Population in our Country Academic Achievement Test (PCAAT) was used to compare the pre-test scores of the groups before starting implementation. One-way ANOVA analysis revealed no statistically significant difference at the $\mathrm{p}<.05$ level between the groups $\left[\mathrm{F}_{(2,91)}=0.267, \mathrm{p}=0.767\right]$. Thus, we assumed that the three groups had similar conditions, as there was no statistically significant difference between the pre-test scores of the groups.

\section{Data Collection Tools}

Population in our country academic achievement test (PCAAT). We developed an academic achievement test, Population in our Country Academic Achievement Test (PCAAT), to determine the effect of ABSL approach on students' academic achievement. First of all, we examined a current Turkish seventh grade social studies curriculum and determined targeted learning outcomes related to "Population in Country" unit. Then, we created a table of specifications covering the subjects and learning objectives of the related unit (scope validity). In the preparation of the questions in the academic achievement test, we took into consideration the cognitive domain learning steps in the Bloom Taxonomy.

In the preparation process of the academic achievement test questions, we used seventh grade social studies textbooks, achievement test preparation books by different publishers, and online achievement test questions prepared by professional educational organizations. For the purpose of construct validity, we obtained experts' opinions. To do so, we asked (a) professors in social studies education, geography education, measurement and evaluation in a research university, and (b) three social studies teachers to determine construct validity of the prepared questions. Based on the feedback from the experts, we made necessary changes and corrections to the test items, and prepared a multiple-choice (i.e., four choices) draft of the academic achievement test consisting of a total of 37 questions. As a pilot study, the draft of the academic achievement test was applied to 96 middle school students in eighth grade during 2016 fall and 2017 spring semesters in three different schools where the targeted unit was previously taught. Then, the data obtained from the pilot study was entered into a computer file and item analysis was performed with TestAn Test Analysis program. As a result of the item analysis, item difficulty and item discrimination indexes for each item included in the test were calculated. Ideally, the average of item difficulty index of the test items should be 0.50 (Kan, 2017; Karaca, 2016), the item discrimination index value should be above .30 and it becomes better as the value gets closer to +1 (At1lgan, 2017; Baştürk, 2014; Kan, 2017; Karaca, 2016).

As a result of the item analysis, the items with item discrimination index of .30 or higher and the item difficulty index between .40 and .69 were included in the academic 
achievement test. We excluded the items with item discrimination index .19 and below (i.e., 1, 4, 10, 15, and 20) and item difficulty index below .40 (i.e., 1, 4, 10, 15, 17, 20, and 36) from the academic achievement test. We calculated the average of item difficulty index of the 30 test questions in the academic achievement test as .51 in the final form of the test.

After item analysis and calculating the average of item difficulty index, we calculated The Kuder-R1chardson-20 (KR-20) coefficient to determine the reliability of the test items and the reliability of the test to determine the reliability of the test results. In other words, we calculated the KR-20 coefficient to determine the internal consistency of the test items. Having the KR-20 value close to 1.00 means that items in tests are consistent with each other while the value of 0.00 shows no consistency (Kan, 2017). In the literature, we verified that a test providing reliable measurements should have at least a KR-20 value of .70 and above (Fraenkel, Wallen \& Hyun, 2012). For the developed test, PCAAT, in this study, we calculated the KR-20 value as .78.

Semi-structured interview form. In this study, we used a semi-structured interview form to support the quantitative data and examine student views of the implemented ABSL approach. Firstly, we prepared a draft interview form. We used related literature to prepare interview questions. Then, we shared the first draft of the interview form with experts and finalized the interview form in accordance with the feedback received from the experts. We conducted interviews with 10 students in the EG determined by the maximum variation purposive sampling method. We recorded interviews with an audio recorder. We informed students that their credentials would be kept confidential and their names would be coded (e.g., S1, S2, S3,...S10) in the study.

Design of Material Guideline and Implementation Process. In this research study, we planned the material guideline and implementation process based on ADDIE instructional design model. The ADDIE instructional design model consists of five stages including analysis, design, development, implementation, and evaluation (Akkoyunlu, Altun \& Yilmaz-Soylu, 2008; Ocak, 2011; Şimşek, 2009). A flowchart of the ADDIE instructional design model is shown in Figure 2. 


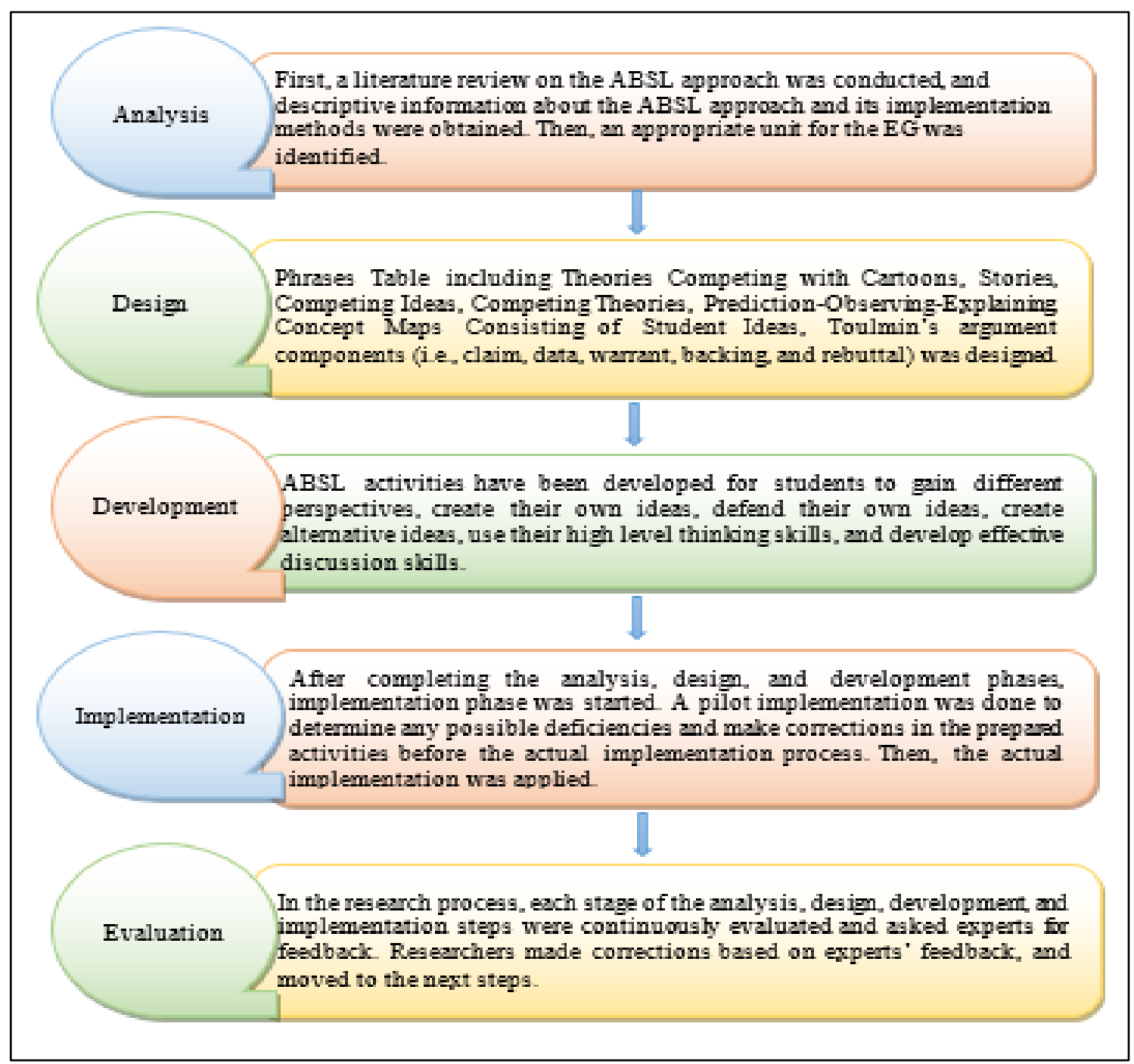

Figure 2. ADDIE instructional design model

The exemplary argumentation activity for the ABSL implementation process is shown in Figure 3. 


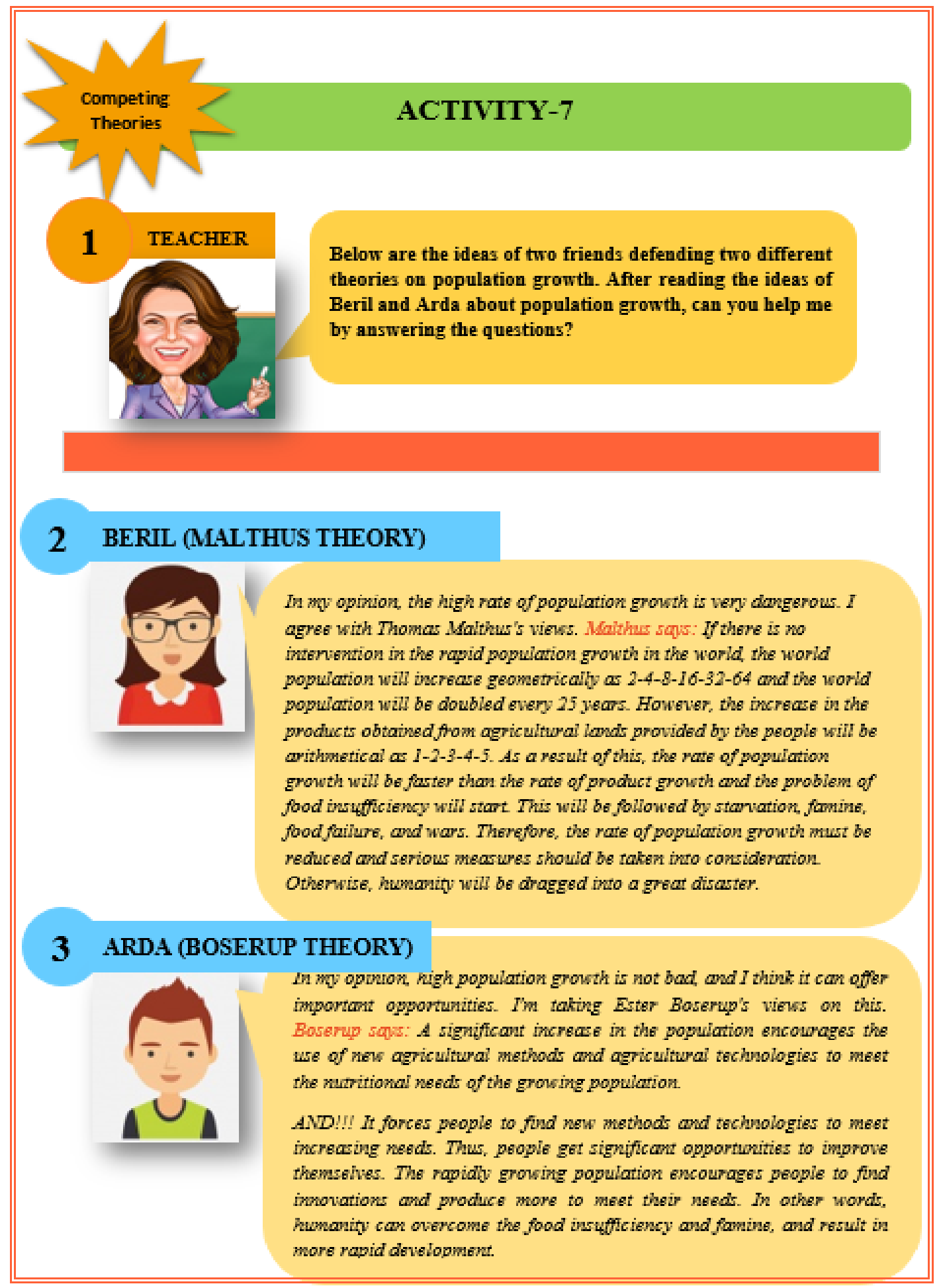




\section{NOW!!! LET'S ANSWER THE QUESTIONS FOR BERIL AND ARDA.}

1. Do you think is the opinion of MALTHUS expressed by Beril or the opinion of BOSERUP expressed by Arda right? Why did you make such a choice? Could you write down your reasons?

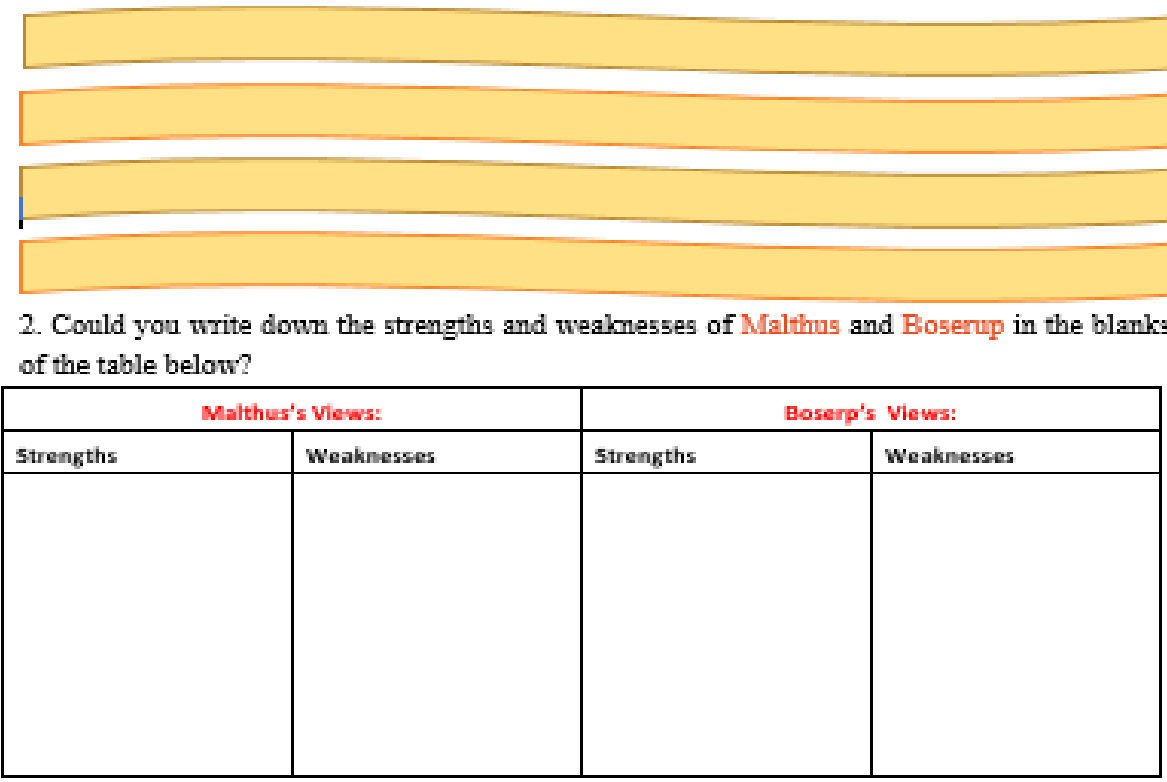

3. The ideas of the philosopher who you digagree with, in what circumstances can the philosopher be right or what would be the philosopher's right sides? Could you write down?

4. What would you say to convince a friend who doean't agree with your views on population growth?

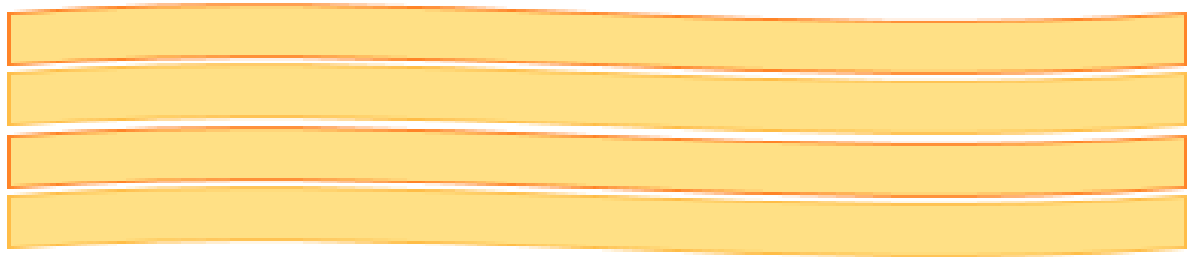

Figure 3. Exemplary argumentation activity 


\section{Implementation Process}

Pilot Implementation. In 2017-spring semester, we carried out a pilot implementation of this study with 60 students in two different classrooms of a middle school located in Yakutiye district of Erzurum, Turkey. Before starting the pilot implementation, we informed social studies classroom teacher about the ABSL approach and provided a guideline explaining how to implement the ABSL approach. Then, in order to get students familiar with the ABSL approach, exemplary argumentation activities were carried out in the first week (3 lesson hours) of the pilot implementation process. This pilot implementation lasted in eight weeks (24 lesson hours). As a result of the pilot implementation, we determined deficiencies in the pilot implementation process and in the prepared activities, made necessary corrections before the actual implementation. Some pictures from the pilot implementation can be seen in Figure 4.
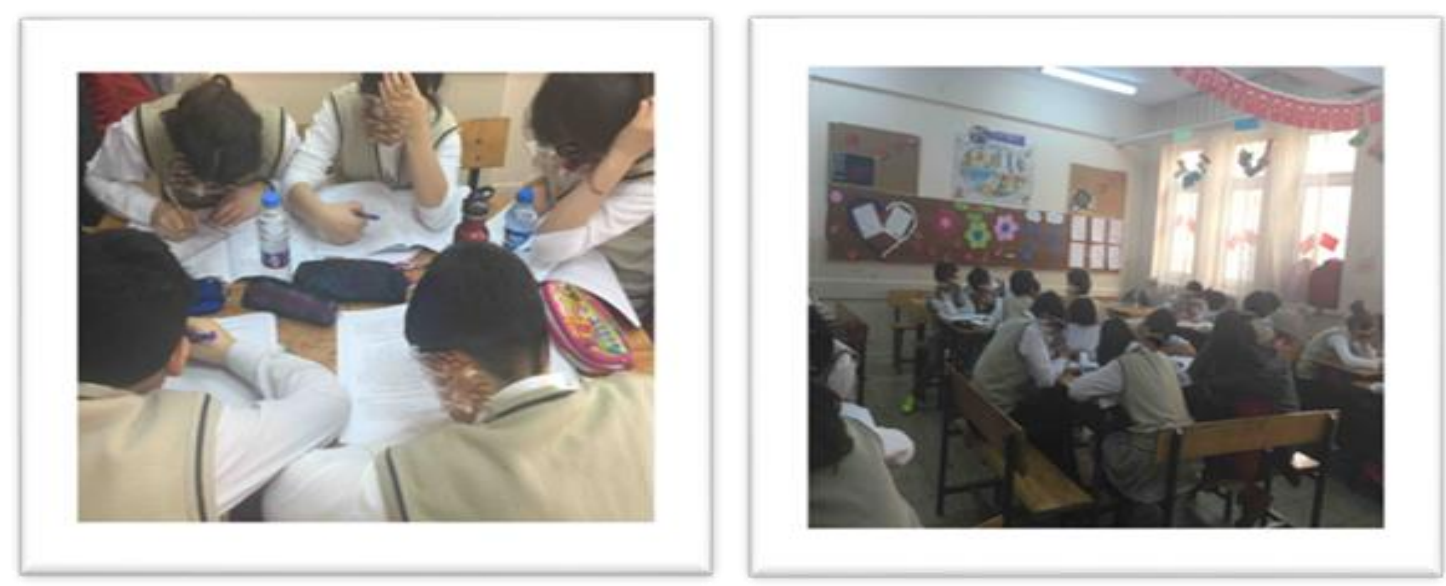

Figure 4. Pictures from the pilot implementation process

Actual Implementation. We carried out the actual implementation of the study with 94 students studying in three different classrooms in a middle school in Yakutiye district of Erzurum, Turkey in the 2017 fall semester. The actual implementation was 3 lesson hours per week and lasted 8 weeks to complete. Subjects were taught with ABSL approach in the EG while subjects were taught with traditional classroom teaching approach in the control groups. The actual implementation process can be seen in Figure 5. 


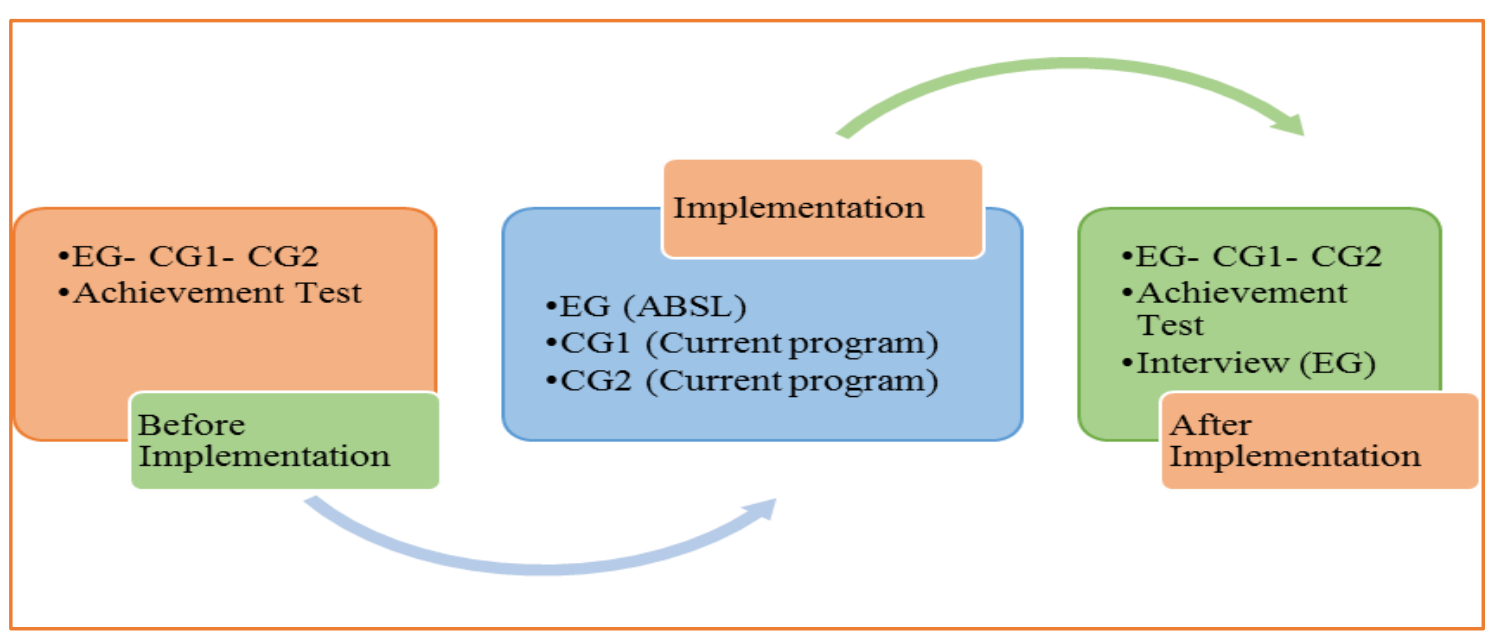

Figure 5. The actual implementation process

Experimental group course process. In the EG, targeted subjects were taught with ABSL approach. In order for the implementation process to be carried out regularly, we prepared a weekly lesson plan including the subjects and activities for each topic. A copy of the weekly lesson plan is outlined in Table 2.

Table 2.

Weekly Lesson Plan

\begin{tabular}{lll}
\hline Week & Subject & Activity \\
\hline 1 & Informing students about purpose of the research. & Pre-test \\
\hline 2 & Places We Live in & Concept cartoon (ABSL) \\
& Population & Interpretation of maps \\
& Distribution of population & Concept map (ABSL) \\
& Factors affecting the distribution of population & \\
\hline 3 & Characteristics of Our Population & Concept cartoon (ABSL) \\
& Census & Table \& chart \\
& Population growth & interpretation \\
\hline 4 & Distribution of population by age groups & Competing theories \\
& Distribution of population by gender & (ABSL) \\
& Ratio of working population, & Predict-observe-explain \\
& Literacy rate & (ABSL) \\
& Rural-urban population & Expressions table \\
& & (ABSL) \\
\hline
\end{tabular}




\begin{tabular}{lll}
\hline 5 & Migration in our Country & Concept cartoon (ABSL) \\
& Migration and causes of migration & A migration story \\
\hline 6 & Results of migration & Competing ideas (ABSL) \\
& Types of migration & Concept cartoon (ABSL) \\
\hline 7 & Our Rights and Freedom & Concept cartoon (ABSL) \\
& Freedom of settlement and travel & News (ABSL) \\
& Employment and education rights & Crossword \\
\hline 8 & Overall evaluation & Post-test \\
\hline
\end{tabular}

The activities prepared in line with the objectives of "Population in Our Country" unit were implemented in 24 lesson hours (3 lessons per week in 8 weeks) in the EG as planned in the teacher guideline. We designated the first and last week of the implementation process for pre- and post-tests and planned the rest of 6 weeks for teaching subjects. In the EG, the course process was organized according to the $5 \mathrm{E}$ model steps (i.e., Engage, Explore, Explain, Extend, and Evaluate) to effectively implement the ABSL approach. To familiarize students with the ABSL approach implementation process, we assisted the implementation process to make sure that students understood the activities correctly in the first three weeks of actual implementation. We divided students into groups containing five students in each group. Then, we asked to gather with their group members and provided guidelines and materials about the activities. We explained the guideline to students and asked them to follow the provided guideline during the activities. After teaching the basics of argumentation and initial preparation process, the teaching of subjects with the ABSL approach was started. In order to increase students' interest and attract their attention, an activity called "Mysterious Event" was completed before teaching the subjects. In the mysterious event activity, we asked students to create their claims about the given incident and present their arguments to their friends by supporting the arguments with appropriate data and justifications. Once we increased students' interest and attention with the mysterious event activity, social studies teacher initiated teaching the subjects by following the $5 \mathrm{E}$ model steps as explained in the teacher guideline.

During the argumentation activities, firstly, students were asked to provide their individual arguments. Next, the teacher asked students to share their individual arguments with other group members, defend their arguments by using argument components, and persuade other group members in case of having different claims in each group. Then, the teacher asked each group to gather their arguments and one group member as a reporter in each group reported their arguments to other groups in the classroom. Small group discussions were held to let groups defend and discuss their claims with other groups in the classroom. Some pictures from actual implementation are exhibited in Figure 6. 

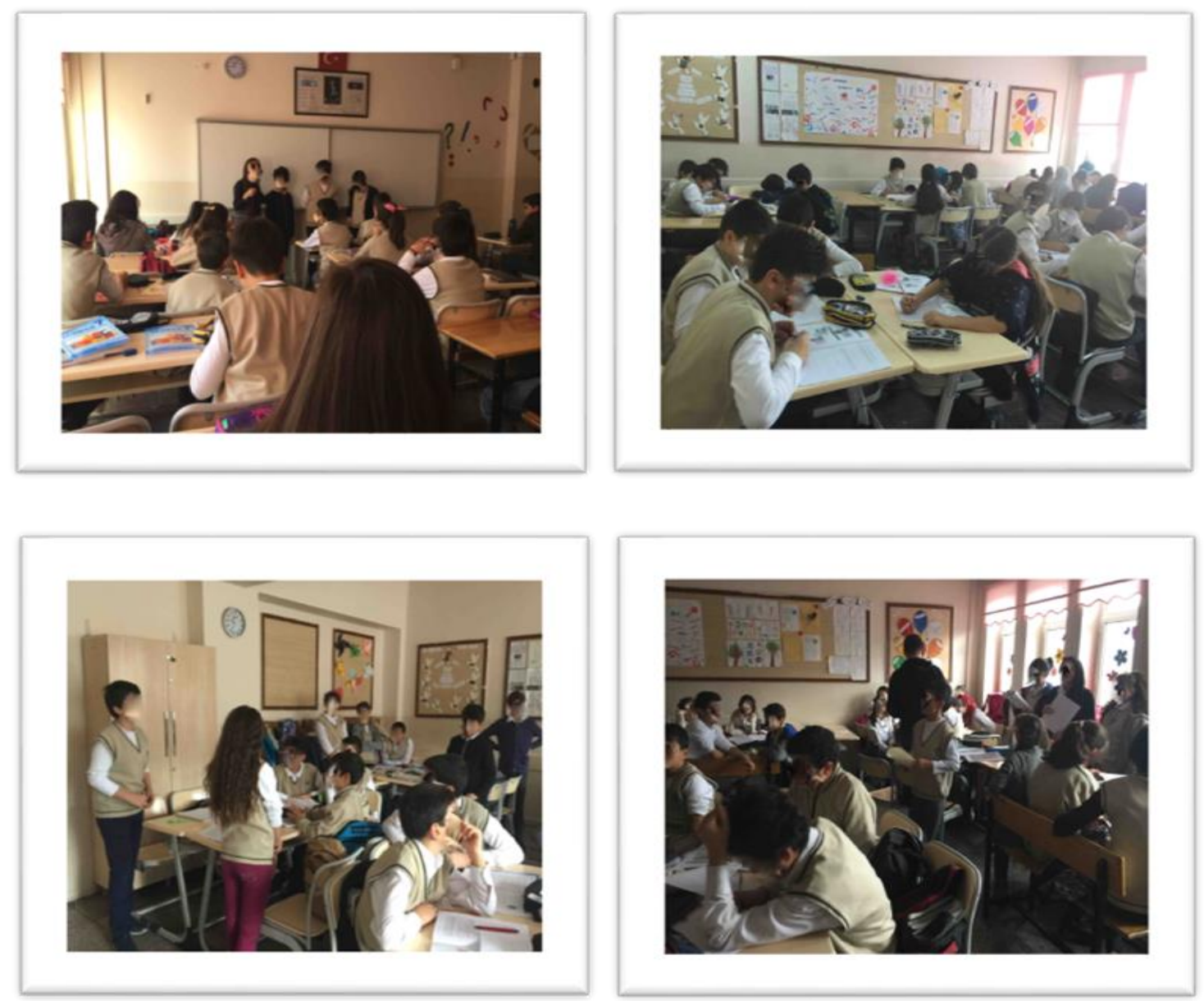

Figure 6. Pictures from actual implementation

Control group course process. In the control groups, a researcher of this study and a social studies teacher taught subjects with traditional teaching approach by following current social studies program. The researcher taught subjects in CG1 and the social studies teachers taught subjects in CG2 in which instructors (a) presented subjects, (b) asked questions and received answers, (c) checked students' understanding with questions and provided additional explanations when necessary (d) did written traditional assessments about covered subjects and discussed the assessment questions and answers with students after the assessment process, and (e) asked students to get prepared for next subjects. Following the same procedure each week, the teaching of the population in our country unit was completed in the control groups.

\section{Data Analysis}

We used quantitative and qualitative data analysis methods in the analysis of the data collected in this research study. We analyzed the quantitative data with SPSS 24.0 package program using predictive and descriptive statistical analysis methods, and used content analysis method in the analysis of qualitative data. Prior to the actual data 
analysis, we did an analysis preparation. Figure 7 shows the preparation process of data analysis.

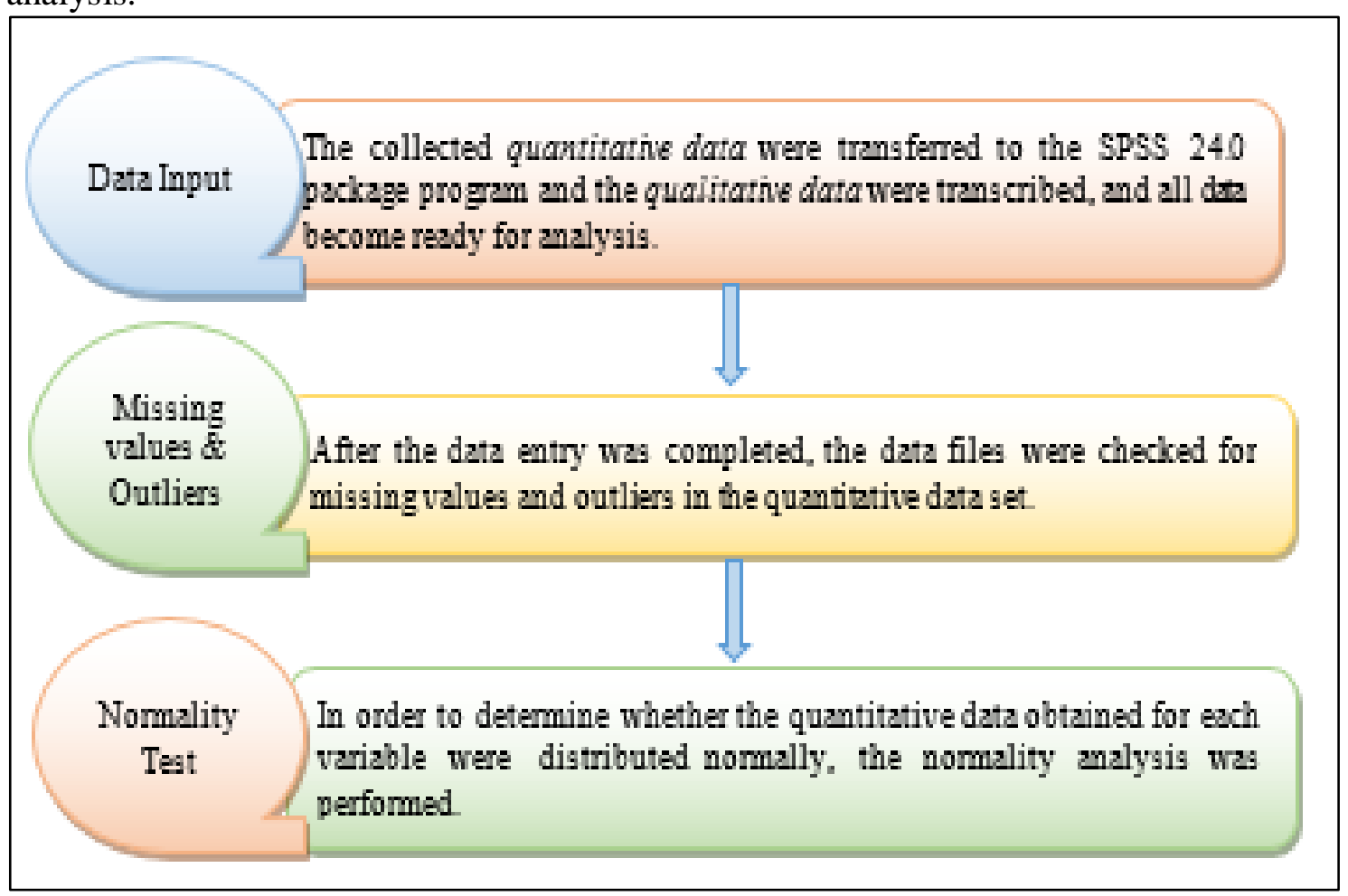

Figure 7. The preparation process of data analysis

After we arranged the data set, we utilized normality analyses to determine which of the parametric or nonparametric tests would be used for research questions. Since numbers of students in the study groups (i.e., EG, CG1, and CG2) were 30, 31, and 33 respectively, we used Kolmogorov Smirnov test for normality analyses (Can, 2017; Karaatl1, 2017). To check whether the data were normally distributed, we examined histogram, normal Q-Q plot, and detrended normal Q-Q plot by looking at skewness and skewness values (Can, 2017; Pallant, 2005; Tabachnick \& Fidell, 2015). Results of normality analyses revealed that using parametric tests were appropriate.

We calculated students' academic achievement scores by using the data obtained from the pre- and post-tests of PCAAT instrument in the experimental and control groups. We used a one-way ANOVA analysis to determine whether there was any statistically difference between the groups. When we found statistically significant results in the results of ANOVA analyses, we employed Tukey test for post-hoc tests. Then, we calculated the effect size value (eta square) to determine the effect of the ABSL approach implementation. According to related literature, eta square value range is between 0.00 and 1.00, and this value is considered to be small effect size between 0.01 and 0.06 , medium effect size between 0.06 and 0.14 , large effect size 0.14 and above (Can, 2017; Green \& Salkind, 2005; Pallant, 2005). 
Audio records of interviews with the students in the EG were transcribed to have the interviews in written texts form for qualitative data analyses. We used content analysis method to analyze transcribed interviews. In the content analysis process, we examined the transcribed interviews carefully and created codes. We read the transcriptions several times and gathered similar codes under appropriate categories. In order to ensure the reliability of coding and category creation process, two faculty members, who were experts in the field, coded the transcriptions independently and collected the codes under appropriate categories. Then, for the consensus and disagreements between the researchers of this study and two experts, we calculated reliability by using the formula of Miles and Huberman [i.e., (Reliability = consensus number / (total number of consensus + number of disagreements)]. In qualitative studies, 90\% agreement level between expert and researcher evaluations is desired (Miles \& Huberman, 2016). In this study, we found $95 \%$ reliability between researchers and experts. After receiving expert feedback, we made the necessary corrections and completed the analysis process. Results are presented in tables. Student expressions are provided with blinded names such as S1, S2, S3, ... S10. We made no changes or corrections in the students' expressions. Excerpts from students' interviews are shown in the results section.

\section{Results}

\section{Results on the Effects of the ABSL Approach on Students' Academic Achievement}

In order to determine the effects of the ABSL approach on students' academic achievement, we used the PCAAT instrument as pre- and post-tests in the experimental and control groups.

PCAAT pre-test results. We used PCAAT instrument to compare the pre-test academic achievement scores of the groups before starting implementation. Since normality analyses of the pre-test academic achievement scores showed normal distribution, we utilized one-way ANOVA as an appropriate parametric test. Descriptive statistics of PCAAT pre-test results are shown in Table 3.

Table 3

Descriptive Statistics of PCAAT Pre-test Results

\begin{tabular}{lccc}
\hline Group & $\mathrm{N}$ & $\bar{X}$ & $\mathrm{SD}$ \\
\hline EG & 33 & 66.24 & 13.75 \\
CG1 & 30 & 63.67 & 14.62 \\
CG2 & 31 & 65.29 & 13.91 \\
\hline Total & 94 & 65.11 & 13.97 \\
\hline
\end{tabular}

As seen in Table 3, the mean scores of the students in the experimental and control groups (i.e., $\mathrm{EG}=66.24, \mathrm{CG} 1=63.67, \mathrm{CG} 2=65.29$ ) were close to each other. We performed one-way ANOVA analysis to determine whether there was a significant difference between the pre-test academic achievement scores of the students in the experimental and control groups, and results are documented in Table 4. 
Table 4

PCAAT Pre-test One-Way ANOVA Results

\begin{tabular}{lccccc}
\hline Groups & Sum of Squares & df & Mean Square & F & p \\
\hline Between Groups & 105.822 & 2 & 52.911 & .267 & \multirow{2}{*}{.76} \\
Within Groups & 18059.114 & 91 & 198.452 & & \\
\hline Total & 18164.936 & 93 & & & \\
\hline
\end{tabular}

Results of one-way ANOVA analysis revealed that there was no statistically significant difference between the groups in terms of academic achievement according to the data obtained from the PCAAT applied to students before starting implementation $\left[\mathrm{F}_{(2,91)}=0.267, \mathrm{p}=0.76\right]$.

PCAAT post-test results. Normality analyses of the post-test academic achievement scores showed normal distribution; therefore, we used one-way ANOVA test. Descriptive statistics of PCAAT post-test results are shown in Table 5.

Table 5

Descriptive Statistics of PCAAT Post-test Results

\begin{tabular}{llcc}
\hline Group & $\mathrm{N}$ & $\bar{X}$ & SD \\
\hline EG & 33 & 87.21 & 8.824 \\
CG1 & 30 & 68.73 & 12.343 \\
CG2 & 31 & 69.06 & 17.468 \\
\hline Total & 94 & 65.11 & 13.97 \\
\hline
\end{tabular}

Descriptive statistics of PCAAT post-test traced that the group with the highest mean score was EG (87.21), and followed by CG2 (69.06) and CG1 (68.73). We employed one-way ANOVA analysis to determine whether the differences were statistically significant, and the results obtained from the analysis are given in Table 6.

Table 6

PCAAT Post-test One-Way ANOVA Results

\begin{tabular}{lccccc}
\hline Groups & Sum of Squares & df & Mean Square & F & p \\
\hline Between & 7181.524 & 2 & 3590.762 & & \\
Groups & & & & 20.342 & .00 \\
Within Groups & 16063.253 & 91 & 176.519 & & \\
\hline Total & 23244.777 & 93 & & & \\
\hline
\end{tabular}

Results of PCAAT Post-test One-Way ANOVA revealed statistically significant difference between groups, $\left[\mathrm{F}_{(2,91)}=20.342, \mathrm{p}=0.00\right]$. The effect size value (Eta squared) was calculated as $\eta^{2}=0.30$ and this value indicated a large effect size. To find out which groups were in favor of this difference, we used Tukey test for post-hoc tests since the variances were distributed homogeneously and differences between group numbers were not high. Results of multiple comparisons Tukey test are provided in Table 7. 
Table 7

Experimental and Control Groups Multiple Comparison Tukey Test Results

\begin{tabular}{lllll}
\hline Groups & Compared Groups & Mean Difference & Std. Error & $\mathrm{p}$ \\
\hline EG & CG1 & $18.479^{*}$ & 3.352 & $.00^{*}$ \\
& CG2 & $18.148^{*}$ & 3.323 & $.00^{*}$ \\
\hline CG1 & EG & $-18.479^{*}$ & 3.352 & $.00^{*}$ \\
& CG2 & -.331 & 3.403 & .99 \\
\hline CG2 & EG & $-18.148^{*}$ & 3.323 & $.00^{*}$ \\
& CG1 & .331 & 3.323 & .99 \\
\hline
\end{tabular}

$* \mathrm{p}<0.05$ level shows the group in favor of the significant difference

We examined the results of multiple comparison Tukey test between the experimental and control groups, verified that the significant difference between EG and CG1, EG and CG2 in the final test were in favor of EG. There was no statistical difference between CG1 and CG2. The average scores of the pre-test and post-test of the groups are shown in Figure 8.

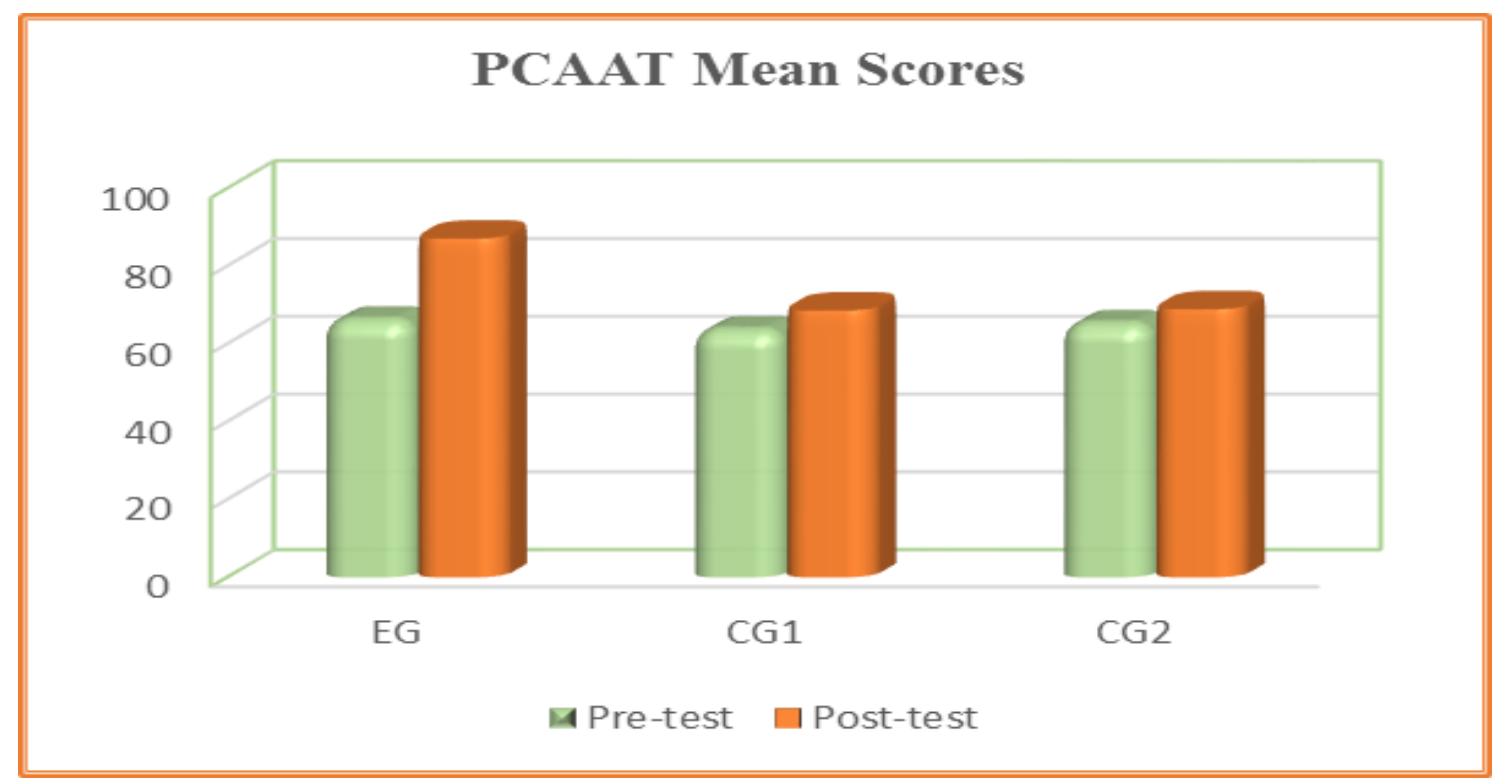

Figure 8. PCAAT pre- and post-test mean scores of groups

When we compared PCAAT pre-test and post-test mean scores of the groups, we confirmed that the average scores of EG, CG1 and CG2 increased. We verified that the highest increase was in the mean scores of EG students (Figure 8).

Results regarding students' views on the ABSL approach. We asked nine questions to the students in the EG to learn their views about the ABSL approach. Then, we analyzed the answers of the students via content analysis method. In the content analysis, we created codes and collected the created codes under appropriate categories. The results are presented in tables and explained in detail in the next section. 


\section{Students' Views on the Differences Created By the ABSL Approach Implementation}

To identify students' views on the differences created by the ABSL approach implementation we asked students, "Did the practices in the lessons conducted with the ABSL approach make any difference in the way that the social studies course was taught? If so, would you please explain the differences?" The views of students about this question are presented in Table 8.

Table 8

Students' Views about Differences created with ABSL Approach Practices

\begin{tabular}{|c|c|c|c|}
\hline Category & Students & Sample Student Statement & $\mathrm{f}$ \\
\hline $\begin{array}{l}\text { Expressing } \\
\text { ideas }\end{array}$ & $\begin{array}{l}S_{1}, S_{5}, S_{6}, \\
S_{7}\end{array}$ & $\begin{array}{l}\text { "I think it was. Because I'd always been memorizing in the } \\
\text { class lectures. I learned how to learn by adding my ideas to } \\
\text { the information through the argumentation process of this } \\
\text { course. In our previous lessons, our teacher was trying to } \\
\text { give more information. We didn't have time to express our } \\
\text { ideas much. While you were teaching this course with } \\
\text { argumentation, you gave us more opportunities to express } \\
\text { our ideas. (S1)" }\end{array}$ & 4 \\
\hline $\begin{array}{l}\text { Understanding } \\
\text { the lesson } \\
\text { better }\end{array}$ & $\begin{array}{l}S_{3}, S_{5}, S_{6}, \\
S_{7}\end{array}$ & $\begin{array}{l}\text { "Our teacher was lecturing the social studies lesson in class } \\
\text { and we were regurgitating at home again. But now, because } \\
\text { I didn't recite the information with argumentation method } \\
\text { and thought more, I understood the lesson better. (S3)" }\end{array}$ & 4 \\
\hline $\begin{array}{l}\text { Become more } \\
\text { active in the } \\
\text { class }\end{array}$ & $\begin{array}{l}\mathrm{S}_{3}, \mathrm{~S}_{5}, \mathrm{~S}_{8}, \\
\mathrm{~S}_{9}\end{array}$ & $\begin{array}{l}\text { "Yes, it made a difference. For example, the teacher usually } \\
\text { lectured lessons and we were keeping notes. Then he was } \\
\text { giving us homework. This time it was different. We tried to } \\
\text { learn first by ourselves. We discussed our ideas. We were } \\
\text { more active. You just directed us (S8)" }\end{array}$ & 4 \\
\hline $\begin{array}{l}\text { Learning with } \\
\text { fun }\end{array}$ & $\mathrm{S}_{2}, \mathrm{~S}_{4}, \mathrm{~S}_{10}$ & $\begin{array}{l}\text { "Yes, it made a difference. Our teacher was talking about } \\
\text { the subjects directly. This course of social studies was more } \\
\text { fun with the argumentation approach. I used to be a little } \\
\text { bored in the social studies class. I've never been bored in } \\
\text { this process. I learned the topic with fun (S4)" }\end{array}$ & 3 \\
\hline $\begin{array}{l}\text { Learning with } \\
\text { cause and } \\
\text { effects }\end{array}$ & $\mathrm{S}_{3}, \mathrm{~S}_{10}$ & $\begin{array}{l}\text { "I learned how to think with this approach because before, } \\
\text { when I encountered a question in the social studies test, I } \\
\text { was immediately marking an A and I was passing. I learned } \\
\text { how to think that the correct answer is correct and why the } \\
\text { wrong answer is wrong after processing our lessons with } \\
\text { the argumentation approach (S10)" }\end{array}$ & 2 \\
\hline
\end{tabular}

As seen in Table 8, students expressed their opinions better, understood the lessons better, became more active in the class, learned subjects with fun, and learned the subjects with cause and effects relations through the ABSL approach. 


\section{Students' Views about Positive Sides of the Implementation of the ABSL Approach}

We asked students, "What would you say about positive sides of ABSL approach implementation process?" The views of students for this question are shown in Table 9.

Table 9

Students' Views about Positive Sides of ABSL Approach Implementation Process

\begin{tabular}{|c|c|c|c|}
\hline Category & Students & Sample Student Statement & $\mathrm{f}$ \\
\hline $\begin{array}{l}\text { Detailed and } \\
\text { interpretive } \\
\text { learning }\end{array}$ & $\mathrm{S}_{3,} \mathrm{~S}_{5}$ & $\begin{array}{l}\text { "The positive aspects of this approach, for example, our } \\
\text { teacher was teaching the population in our country unit } \\
\text { in one or two weeks and we were moving to the next unit. } \\
\text { But you taught the unit differently. First, you let us learn } \\
\text { ourselves. Then you taught. We created arguments and } \\
\text { shared our ideas. So we learned more in detail. We } \\
\text { learned this by interpreting the subject in different ways } \\
\text { and understood it better (S3)" }\end{array}$ & 2 \\
\hline $\begin{array}{l}\text { Becoming more } \\
\text { confident }\end{array}$ & $\mathrm{S}_{5}, \mathrm{~S}_{6}$ & $\begin{array}{l}\text { "I used to be shy before. I couldn't share my ideas with } \\
\text { my friends. Thanks to this approach, my confidence } \\
\text { increased. This approach enabled me to take the right to } \\
\text { speak comfortably without thinking that my ideas were } \\
\text { wrong or not (S5)" }\end{array}$ & 2 \\
\hline $\begin{array}{l}\text { Expressing } \\
\text { yourself and your } \\
\text { ideas better }\end{array}$ & $\mathrm{S}_{6}, \mathrm{~S}_{10}$ & $\begin{array}{l}\text { "This approach enabled me to better express myself and } \\
\text { my ideas verbally. The most positive aspect of this } \\
\text { approach was that we could support our own ideas, } \\
\text { assert ourselves, and defend ourselves in a beautiful way } \\
\text { (S6)" }\end{array}$ & 2 \\
\hline $\begin{array}{l}\text { Learning by } \\
\text { thinking of cause } \\
\text { and effects }\end{array}$ & $\mathrm{S}_{8}$ & $\begin{array}{l}\text { "Positive sides, for example, when I encounter a problem } \\
\text { my friend says this, I say I agree, I try to convince him. I } \\
\text { wouldn't accept something my friend said. I decide with } \\
\text { reason and consequences (S8)" }\end{array}$ & 1 \\
\hline $\begin{array}{l}\text { Communicating } \\
\text { easier }\end{array}$ & $S_{10}$ & $\begin{array}{l}\text { "Our teacher was lecturing the lesson and we were } \\
\text { listening. We were not having any communication with } \\
\text { our friends. Thanks to this approach, I even } \\
\text { communicated with my friends that I didn't talk before } \\
\text { (S10)" }\end{array}$ & 1 \\
\hline $\begin{array}{l}\text { Being more } \\
\text { active in the } \\
\text { course }\end{array}$ & $\mathrm{S}_{4}$ & $\begin{array}{l}\text { "You did not teach the lesson directly. At first you asked } \\
\text { questions, you made us think. We entered into learning } \\
\text { ourselves. We became more active in the course (S4)" }\end{array}$ & 1 \\
\hline $\begin{array}{l}\text { Learning with } \\
\text { fun }\end{array}$ & $\mathrm{S}_{7}$ & $\begin{array}{l}\text { "Our teacher was talking about subjects, we were } \\
\text { listening. We were so bored and feeling sleepy. We had } \\
\text { discussions in the lesson with argumentation, and good } \\
\text { things came up during the discussions. The lesson was } \\
\text { more fun. We learned with fun (S7)" }\end{array}$ & 1 \\
\hline $\begin{array}{l}\text { Getting away } \\
\text { from } \\
\text { memorization }\end{array}$ & $\mathrm{S}_{1}$ & $\begin{array}{l}\text { "I wasn't only memorized the information, but the } \\
\text { information I learned with different aspects. So I got } \\
\text { away from memorization (S1)" }\end{array}$ & 1 \\
\hline
\end{tabular}


As shown in Table 9, students' views about positive sides of the ABSL approach included detailed and interpretive learning, becoming more confident, expressing himself/herself ideas better, learning by thinking of cause and effects, easier communication, being more active in the course, learning with fun, getting away from memorization.

\section{Students' Views about Negative Aspects of the Implementation of the ABSL Approach}

We asked students in the study, "What would you say about negative sides of ABSL approach implementation process?" Students' views regarding this question are displayed in Table 10.

Table 10

Students' Views about Negative Sides of ABSL Approach Implementation Process

\begin{tabular}{|c|c|c|c|}
\hline Category & Students & Sample Student Statement & $\mathrm{f}$ \\
\hline $\begin{array}{l}\text { Having } \\
\text { problems in } \\
\text { discussion } \\
\text { process }\end{array}$ & $\begin{array}{l}\mathrm{S}_{2,} \mathrm{~S}_{3,} \mathrm{~S}_{4}, \mathrm{~S}_{6}, \\
\mathrm{~S}_{7}, \mathrm{~S}_{8}\end{array}$ & $\begin{array}{l}\text { "There is not much I can say negative. While we } \\
\text { were just defending our thoughts, our friends were } \\
\text { very impatient during our discussions. This also } \\
\text { caused conflicts (S8)" }\end{array}$ & 6 \\
\hline $\begin{array}{l}\text { The difficulties } \\
\text { due to the } \\
\text { inexperienced } \\
\text { process at the } \\
\text { beginning }\end{array}$ & $\mathrm{S}_{1}, \mathrm{~S}_{5}, \mathrm{~S}_{10}$ & $\begin{array}{l}\text { "I didn't get used to it. Because I used to receive } \\
\text { prepared information. Because of this, I had } \\
\text { difficulties because I had difficulties at the } \\
\text { beginning. Then I got used to it and loved it (S5)" }\end{array}$ & 3 \\
\hline No negativity & $\ddot{O}_{9}$ & $\begin{array}{l}\text { "There was nothing that could be negative. You } \\
\text { planned everything very well in the class. } \\
\text { Therefore, I had no problems (S9)" }\end{array}$ & 1 \\
\hline
\end{tabular}

Students emphasized that they had problems, especially in the discussion process. While the students stated that they experienced difficulties due to their inexperience at the beginning of the implementation process, one student indicated that she/he had no negativity.

\section{Students' Views about the Courses in Which They Want To Use the ABSL Approach and Their Reasons}

We asked students, "Do you want to use the ABSL approach in other courses? Why is that?" The views of students about this question are illustrated in Table 11. 
Table 11

Students' Views about Courses in Which They Want to Use the ABSL Approach and Their Reasons

\begin{tabular}{|c|c|c|c|c|}
\hline \multirow{5}{*}{ Turkish } & Category & Students & Sample Student Statement & f \\
\hline & $\begin{array}{l}\text { Providing } \\
\text { opportunities to } \\
\text { think }\end{array}$ & $\begin{array}{ll}\mathrm{S}_{2,} & \mathrm{~S}_{7,} \\
\mathrm{~S}_{10} & \end{array}$ & $\begin{array}{l}\text { "Yes, I would. For example, I would like to be } \\
\text { used in Turkish literature class. Because, in } \\
\text { Turkish literature class, the teacher gives a } \\
\text { topic. Then, she asks to create a story about the } \\
\text { topic. And that requires me to think more. With } \\
\text { this approach I think I can make it easier (S7)" }\end{array}$ & 3 \\
\hline & $\begin{array}{l}\text { Better } \\
\text { understanding } \\
\text { of the course }\end{array}$ & $\mathrm{S}_{6}, \mathrm{~S}_{8}$ & $\begin{array}{l}\text { "I would like to use it in Turkish literature } \\
\text { because our teacher usually writes something, } \\
\text { lectures and finishes. That's why I don't } \\
\text { understand much. I'd better understand it by } \\
\text { the argumentation method (S8)" }\end{array}$ & 2 \\
\hline & $\begin{array}{l}\text { Learning topics } \\
\text { with inquiry }\end{array}$ & $\mathrm{S}_{4}$ & $\begin{array}{l}\text { "Actually, I'd love to. Because we tried to learn } \\
\text { the subjects with inquiry the reasons in this } \\
\text { course while we were passing the subject } \\
\text { directly in other courses. My best class is } \\
\text { Turkish. I would like to be used in that course. } \\
\text { I would love to apply it to the contradictory } \\
\text { texts (S4)" }\end{array}$ & 1 \\
\hline & $\begin{array}{l}\text { Suitable for } \\
\text { discussion }\end{array}$ & $\mathrm{S}_{5}$ & $\begin{array}{l}\text { "Yeah. I would like my teacher to be used } \\
\text { especially in Turkish courses. Because, in } \\
\text { verbal subjects, there is always a discussion. I } \\
\text { would like to have it in Turkish because it is } \\
\text { very suitable for discussion (S5)" }\end{array}$ & 1 \\
\hline \multirow{2}{*}{ Science } & $\begin{array}{l}\text { Requiring to } \\
\text { think }\end{array}$ & $\mathrm{S}_{1, \mathrm{~S}_{2}}$ & $\begin{array}{l}\text { "I want. I especially want to be used in science } \\
\text { course. Because this lesson requires us to think } \\
\text { (S2)" }\end{array}$ & 2 \\
\hline & $\begin{array}{l}\text { Difficult } \\
\text { subjects }\end{array}$ & $\mathrm{S}_{1}$ & $\begin{array}{l}\text { "I would like to use it in other courses too. For } \\
\text { example, I would like to use it in science. } \\
\text { Because science is a difficult course. I forget } \\
\text { what I have learned when I learn with } \\
\text { memorizing. I can learn more easily with } \\
\text { argumentation approach (S1)" }\end{array}$ & 1 \\
\hline
\end{tabular}

As seen in Table 11, students stated that they wanted the ABSL approach to be used most in Turkish course and then science course. Students indicated that using the ABSL approach in the Turkish course would provide opportunities to think, help them understand the course better, encourage them to learn with inquiry, be appropriate for discussion. One student did not state any specific reason. For the science courses, the students thought that they would think and perform better in difficult subjects when the ABSL approach was used. Students who wanted this approach to be used in mathematics and English classes did not state any specific reason. 


\section{Students' Views about the Effects of the ABSL Approach Process on Their High-Level Thinking Skills}

We asked students "What do you think about the effects of the ABSL approach process on your high-level thinking skills?" The views of students about this question are depicted in Table 12.

Table 12

Students' Views about the Effects of the ABSL Approach Process on Their High-Level Thinking Skills

\begin{tabular}{|c|c|c|c|}
\hline Category & Students & Sample Student Statement & $\mathrm{f}$ \\
\hline $\begin{array}{l}\text { Thinking with } \\
\text { different aspects }\end{array}$ & $\begin{array}{l}\mathrm{S}_{1}, \mathrm{~S}_{2,} \mathrm{~S}_{3} \\
\mathrm{~S}_{4}, \mathrm{~S}_{5}, \mathrm{~S}_{6} \\
\mathrm{~S}_{7}, \mathrm{~S}_{8}, \mathrm{~S}_{9}\end{array}$ & $\begin{array}{l}\text { "Yes, it happened. I was memorizing the information } \\
\text { before. With this approach, I learned how to think with } \\
\text { different aspects of the information I learned. For } \\
\text { example, when I encountered a problem, a question, it } \\
\text { enabled me to think differently and solve it rather than } \\
\text { by heart (S1)" }\end{array}$ & 9 \\
\hline Justification & $\begin{array}{l}\mathrm{S}_{1}, \mathrm{~S}_{2,} \mathrm{~S}_{3} \\
\mathrm{~S}_{4}, \mathrm{~S}_{5}, \mathrm{~S}_{6} \\
\mathrm{~S}_{7}, \mathrm{~S}_{8}, \mathrm{~S}_{9}\end{array}$ & $\begin{array}{l}\text { "Yes. When my friends told me something about a topic, } \\
\text { I learned not to accept it immediately, try to convince } \\
\text { them on the grounds of my opinion, convince them by } \\
\text { saying my opinion with my reasons. With this approach, } \\
\text { I realized how important was the question of Why. (S2)" }\end{array}$ & 9 \\
\hline $\begin{array}{l}\text { Decision } \\
\text { making with } \\
\text { interpretation }\end{array}$ & $\begin{array}{l}S_{5,}, S_{7}, S_{8}, \\
S_{10}\end{array}$ & $\begin{array}{l}\text { "When I was making a decision about a subject, } \\
\text { thinking about its positive and negative aspects, I } \\
\text { realized that it was important to make a decision by } \\
\text { interpreting (S10)" }\end{array}$ & 4 \\
\hline
\end{tabular}

Student statements about the effects of the ABSL approach process on their highlevel thinking skills indicated that students could express their opinions with different aspects, make justifications, and make decisions with interpretation when the ABSL approach was used.

\section{Students' Views about the Effects of the ABSL Approach on Their Success in Social Studies Course}

Students were asked, "What do you think about the effects of the ABSL approach on your success in social studies course?" The views of students about this question are depicted in Table 13.

Table 13

Students' Views about the Effects of the ABSL Approach on Their Success in Social Studies Course

\begin{tabular}{llll}
\hline Category & Students & \multicolumn{1}{c}{ Sample Student Statement } & $\mathrm{f}$ \\
\hline Permanent & $\mathrm{S}_{1}, \mathrm{~S}_{2}, \mathrm{~S}_{3}$, & "In this process, you did not teach the lesson in advance. First, & 8 \\
learning & $\mathrm{S}_{5}, \mathrm{~S}_{6}, \mathrm{~S}_{7}$, & you directed us. We tried to learn the subject ourselves. We & \\
& $\mathrm{S}_{8}, \mathrm{~S}_{9}$ & were more active in class. We thought ourselves, so what we & learned became more permanent, I did not forget what I \\
& & learned (S9)"
\end{tabular}




\begin{tabular}{lll}
$\begin{array}{l}\text { Easier } \\
\text { learning }\end{array}$ & $\mathrm{S}_{7,}$ & $\mathrm{~S}_{4}, \begin{array}{c}\text { "In the previous lessons we had a straight course. I got lower } \\
\text { scores in my exams. I couldn't understand the subjects well. But } \\
\text { in this approach, we first expressed ourselves. Then I learned } \\
\text { better and learned the subject more easily (S7)" }\end{array}$ \\
\hline
\end{tabular}

As specified in Table 13, the ABSL approach did positive impacts on students' success in social studies course since the approach provided opportunities for permanent and easier learning.

\section{Students' Views about the Activities They Liked Most In the Lessons with the ABSL Approach and Reasons for Their Ideas}

To understand students' favorite activities in the ABSL approach implementation, we asked, "What were your favorite activities in the lessons with the ABSL approach? Could you explain?" The views of students about their favorite activities in the ABSL implementation are demonstrated in Table 14.

Table 14

Students' Views about the Activities They Liked Most in the Lessons with the ABSL Approach and Reasons for Their Ideas

\begin{tabular}{|c|c|c|c|c|}
\hline \multirow{4}{*}{$\begin{array}{c}\text { Competing } \\
\text { Theories }\end{array}$} & Category & Students & Sample Student Statement & $\mathrm{f}$ \\
\hline & $\begin{array}{l}\text { Creating } \\
\text { arguments } \\
\text { easier }\end{array}$ & $\begin{array}{lll}\mathrm{S}_{3}, & \mathrm{~S}_{5,} & \mathrm{~S}_{6}, \\
\mathrm{~S}_{7} & & \end{array}$ & $\begin{array}{l}\text { "I liked the competing theories activity } \\
\text { more because I did the activity easier and I } \\
\text { was able to create my arguments easier } \\
\text { (S6)" }\end{array}$ & 4 \\
\hline & $\begin{array}{l}\text { Reflecting } \\
\text { ideas better }\end{array}$ & $\mathrm{S}_{1}, \mathrm{~S}_{3}, \mathrm{~S}_{7}$ & $\begin{array}{l}\text { "I liked the competing theories activity most } \\
\text { because there was more written text } \\
\text { involved in the activity. It was easier for me } \\
\text { to comment and support my ideas (S3)" }\end{array}$ & 3 \\
\hline & $\begin{array}{l}\text { Commenting } \\
\text { better }\end{array}$ & $\mathrm{S}_{3,} \mathrm{~S}_{5}$ & $\begin{array}{l}\text { "I liked the competing theories activity most } \\
\text { because I was able to defend my claims in a } \\
\text { better way. Having a written text made me } \\
\text { comment better (S5)" }\end{array}$ & 2 \\
\hline \multirow[t]{2}{*}{ News } & $\begin{array}{l}\text { Reflecting } \\
\text { ideas better }\end{array}$ & $\mathrm{S}_{4,} \mathrm{~S}_{7}, \mathrm{~S}_{8}$ & $\begin{array}{l}\text { "My favorite was the newspaper news } \\
\text { activity because I was able to express my } \\
\text { ideas better in this activity. I was able to } \\
\text { defend my ideas based on the components } \\
\text { you provided us during the argumentation } \\
\text { process (S4)" }\end{array}$ & 3 \\
\hline & $\begin{array}{l}\text { Creating } \\
\text { more } \\
\text { arguments }\end{array}$ & $\mathrm{S}_{8}, \mathrm{~S}_{9,} \mathrm{~S}_{10}$ & $\begin{array}{l}\text { "My favorite activity was the news activity } \\
\text { because I was able to use argument } \\
\text { components more easily (S10)" }\end{array}$ & 3 \\
\hline $\begin{array}{l}\text { Concept } \\
\text { Cartoon }\end{array}$ & $\begin{array}{l}\text { Creating } \\
\text { arguments } \\
\text { easier }\end{array}$ & $\mathrm{S}_{2}$ & $\begin{array}{l}\text { "I liked concept cartoons more because I } \\
\text { created a better and easier argument in the } \\
\text { argumentation process. (S2)" }\end{array}$ & 1 \\
\hline
\end{tabular}


As indicated in Table 14, the students specified that they liked the activities of competing theories, news, and concept cartoons respectively since they could create arguments easier, reflect ideas better, and comment on claims better.

\section{Students' Views about the Difficulties They Experienced In the ABSL Approach Implementation Process}

In order to understand the difficulties students experienced in the ABSL approach implementation process, we asked, "Did you have any difficulty with the lessons based on the ABSL approach? If so, what were the most difficult or most disliked activities? Could you explain?" The views of students about the difficulties they experienced in the ABSL approach implementation process are demonstrated in Table 15.

Table 15

Students' Views about the Difficulties They Experienced in the ABSL Approach Implementation Process

\begin{tabular}{|c|c|c|c|c|}
\hline \multirow[b]{3}{*}{$\begin{array}{l}\text { Concept } \\
\text { Cartoons }\end{array}$} & Category & Students & Sample Student Statement & $f$ \\
\hline & $\begin{array}{l}\text { Difficulties in } \\
\text { creating } \\
\text { arguments }\end{array}$ & $\begin{array}{l}S_{3}, S_{4}, S_{6} \\
S_{8}\end{array}$ & $\begin{array}{l}\text { "The most difficult activity for me was the } \\
\text { concept cartoons activity because I had } \\
\text { difficulties in creating arguments (S8)" }\end{array}$ & 4 \\
\hline & No reasons & $\mathrm{S}_{2,} \mathrm{~S}_{10}$ & & 2 \\
\hline & $\begin{array}{l}\text { Difficulties in } \\
\text { creating } \\
\text { arguments }\end{array}$ & $\mathrm{S}_{7}$ & $\begin{array}{l}\text { "I had a little bit in the migration story } \\
\text { because I couldn't create the arguments I } \\
\text { wanted in that activity. (S7)" }\end{array}$ & 1 \\
\hline $\begin{array}{l}\text { A } \\
\text { Migration } \\
\text { Story }\end{array}$ & No difficulties & $\mathrm{S}_{1}, \mathrm{~S}_{5}, \mathrm{~S}_{9}$ & - & 3 \\
\hline
\end{tabular}

Table 15 shows that students had difficulties in a migration story and the concept cartoons activities. Five students identified that they had difficulties in creating arguments during these activities and two students did not give any reasons why they had difficulties. Three students stated that they did not experience any difficulties.

\section{Students' Views about the Effects of the ABSL Approach Implemented Course Process on Their Interest and Attitudes towards Social Studies}

To learn about the effects of the ABSL approach implemented course process on students' interest and attitudes towards social studies, researchers asked, "Did the course process based on the ABSL approach change your interests and attitudes towards social studies? Why is that?" The views of students about this question are presented in Table 16. 
Table 16

Students' Views about the Effects of the ABSL Approach Implemented Course Process on Their Interest and Attitudes towards Social Studies

\begin{tabular}{|c|c|c|c|c|}
\hline \multirow{5}{*}{$\begin{array}{l}\text { Positive } \\
\text { changes }\end{array}$} & Category & Students & Sample Student Statement & $\mathrm{f}$ \\
\hline & More fun lesson & $\begin{array}{l}\mathrm{S}_{2,} \mathrm{~S}_{3}, \quad \mathrm{~S}_{4}, \\
\mathrm{~S}_{7} \mathrm{~S}_{8}, \mathrm{~S}_{9}\end{array}$ & $\begin{array}{l}\text { "Yes, it created sir. I loved it a bit } \\
\text { before. I was bored in class. We were } \\
\text { only continuously listening to the } \\
\text { teacher before. In this approach, the } \\
\text { lessons were more fun because we } \\
\text { participated in the lesson. That's why I } \\
\text { liked the social studies lesson more } \\
\text { (S3)" }\end{array}$ & 6 \\
\hline & $\begin{array}{l}\text { Meaningful } \\
\text { lesson }\end{array}$ & $\mathrm{S}_{1,} \mathrm{~S}_{3}$ & $\begin{array}{l}\text { "I didn't like it much before because the } \\
\text { teacher was telling the information. We } \\
\text { were listening. In the course of the } \\
\text { argumentation process, we became } \\
\text { active in the lesson and learned how to } \\
\text { comment. So the lesson became more } \\
\text { meaningful. My interest and attitudes } \\
\text { towards the course changed more } \\
\text { positively (S1)" }\end{array}$ & 2 \\
\hline & $\begin{array}{l}\text { Facilitating } \\
\text { communication } \\
\text { in the course }\end{array}$ & $\mathrm{S}_{5}, \mathrm{~S}_{10}$ & $\begin{array}{l}\text { "Yes, this approach has changed my } \\
\text { attitudes toward social studies. We } \\
\text { couldn't share our ideas with our } \\
\text { friends before. Getting in groups and } \\
\text { having discussions with our friends in } \\
\text { the argumentation approach enabled us } \\
\text { to communicate (S10)" }\end{array}$ & 2 \\
\hline & $\begin{array}{l}\text { Ensuring critical } \\
\text { thinking }\end{array}$ & $\ddot{O}_{6}$ & $\begin{array}{l}\text { "Yes, I liked this approach very much. } \\
\text { Additionally, my interest in social } \\
\text { studies lesson has increased. I already } \\
\text { liked social studies lesson. I liked the } \\
\text { social studies lesson even more because } \\
\text { I developed critical thinking along with } \\
\text { this practice (S6)" }\end{array}$ & 1 \\
\hline $\begin{array}{l}\text { Negative } \\
\text { changes }\end{array}$ & & - & - & - \\
\hline $\begin{array}{l}\text { No } \\
\text { changes }\end{array}$ & & - & - & - \\
\hline
\end{tabular}

Based on students' responses to the question about the effects of the ABSL approach implemented course process on their interest and attitudes towards social studies, it is noteworthy that there were positive changes in students' interest and attitudes towards social studies after implementation. The students who indicated positive changes stated that the ABSL approach implemented course was fun, meaningful, facilitated communication, and provided critical thinking. Students did not state any negative changes and no change ideas. 


\section{Conclusion, Discussion and Recommendations}

Results of this research study showed that the academic achievement mean scores of the students in EG, CG1, and CG2 groups were close to each other and there was no statistically significant difference between the groups in the pre-test (Table 3 and Table 4). However, the EG students' academic achievement mean scores were higher than those students in CG1 and CG2 (Table 5) and there were statistically significant differences between groups (Table 6) indicating that academic achievement mean scores of students in the EG was statistically higher than students in CG1 and CG2 (Table 7) in the post-test. The reason for the higher academic achievement of the students in the EG could be the implementation of the ABSL approach by allowing students to be more active in the learning process. Additionally, this approach provided opportunities for students to express themselves comfortably, learn the knowledge with inquiry, and make learning fun with discussions. Thus, students were able to learn the targeted knowledge more permanent. Findings of students' interview in the EG also supported these results. In the interviews, students stated that the ABSL activities helped them understand the subjects better, facilitated their learning, provided permanent learning opportunities, increased their interest and attitudes towards the course, and consequently enhanced their success.

These results are parallel with the related studies in the literatures indicating that the ABSL approach facilitates learning and is more effective on students' academic achievement than traditional methods (Altun, 2010; Aydoğdu, 2017; Bozkurt, 2017; Chin \& Osborne, 2010; Ceylan, 2010; Domaç, 2011; Greenbowe, Poock, Burke \& Hand, 2007; Gündüz, 2017; Günel, Kabataş-Memiş \& Büyükkasap, 2010; Hand, Prain \& Wallace, 2002; Hand, Wallace \& Yang, 2004; Hohenshell \& Hand 2006; KabatasMemiş, 2011 ; Kıngır, 2011; Nam, Choi \& Hand, 2011; Okumuş, 2012; Polat, 2014; Poock, 2005; Şahin, 2016; Ulu \& Bayram, 2015; Uluay, 2012; Yeşildağ-Hasançebi \& Günel, 2013; Yeşiloğlu, 2007). Researchers in the previous related studies rationalized that the reason for better academic achievements with the ABSL approach was to provide some extra opportunities for students. Greenbowe et al. (2007) indicated that the ABSL approach provided opportunities for students to be more engaged in the learning process. Günel et al. (2010) affirmed that the ABSL approach positively affected students' attitudes towards subjects, thus, improved their academic achievement levels. In their study, Yeşildağ-Hasançebi and Günel (2013) identified that students' academic achievement increased as a result of the ABSL approach implementation because this approach provided a student-centered learning environment, made the learning environment more efficient and enjoyable, and allowed students to express themselves and criticize different ideas in the process. Şahin (2016) explained that the ABSL approach had positive effects on students' achievements and resulted in permanent learning by facilitating their learning and creating a learning environment different from the learning environments that prevent students from expressing themselves comfortably.

As a result of the study, we observed that students in the EG, who participated in interviews to share their views about the ABSL approach, mostly provided positive 
opinions about the ABSL approach. The students stated that at the beginning of the ABSL implementation they experienced minor problems with their friends during the group discussions because of their novelty to the approach. Other than these minor problems, they encountered no other problems during the implementation process. This result is parallel with the results of the studies in the literature about the examination of students' opinions about the ABSL approach. (Deniz, 2014; Kıngır, Geban \& Günel, 2011; Şahin, 2016). In their research, Kıngır, Geban, and Günel (2011) reported that the majority of students did not experience any problems in the course designed with ABSL approach, but a few students indicated that during their talks in the class, they did not feel comfortable when their friends did not listen to them in the course. Deniz (2014) affirmed that students were generally satisfied with the argumentation-based practices, but a few students complained about long activity duration, difficulties during long discussions, limited participation of some other students in discussions.

In this study, when students were asked whether the ABSL approach made any difference in the teaching of the course, the students noted that the ABSL approach enabled them to be more active in the class. Being active in the learning process made the course more enjoyable and facilitated student learning. This result coincides with the results of the previous research studies on students' views about the ABSL approach (Demirel, 2014; Kabataş-Memiş, 2014; Kıngır, Geban and Günel, 2011). In addition, students addressed that the most positive aspect of this approach was permanent and meaningful learning of subjects within cause and effect relationships by getting away from memorization. Hasançebi (2014) stated in his research that students learned better with the ABSL activities, and the activities facilitated student learning, resulted in permanent learning, and increased students' interest in the course. In the interviews of this study, students indicated that the course process based on the ABSL approach enabled them to use high-level thinking skills. In a research study, Ceylan (2010) reported that with ABSL approach based activities teacher candidates increased their understanding of subjects, active participation in the course, learning with questioning, research and inquiry skills, and scientific thinking skills.

The students' views about the effect of the ABSL approach on their success of social studies course demonstrated that the ABSL approach did positive impacts on students' success in the social studies course. This finding is supported by quantitative findings in which significant differences between groups were determined. Students who thought their academic achievement improved stated that the ABSL approach facilitated the learning process and resulted in permanent learning. This result is similar with the previous studies in which researchers found positive effects of the ABSL approach on students' academic achievement (Günel, et al., 2010; Greenbowe et al., 2007; Hand, Wallace \& Yang, 2004; Hohenshell \& Hand, 2006; Poock, 2005).

Participating students in this study verified that they desired this approach to be used in different courses including Turkish course. They thought that the Turkish course with the ABSL approach would be suitable for discussion and provide opportunities for students thinking. Students reported that with the ABSL approach they were able to create arguments easier, reflect ideas better, and provide more comments in the course. 
In addition, the students noted that they liked the "competing theories" and "news" activities most, and had difficulties in the process of creating arguments during "a migration story" and the "concept cartoons" activities. As a result of the ABSL approach implementation, students' views indicated positive changes in students' interest and attitudes towards social studies. This result is in line with previous studies' results showing the development of positive attitudes towards subjects (Balc1, 2015; Eyceyurt-Türk, 2017; Kana, 2013; Kıngır, 2011; Öztürk, 2013; Şahin 2016; Şekerci, 2013; Tekeli, 2009; Yalçın - Çelik, 2010).

Based on our experiences in this study, we recommend informing students about the implementation process of the ABSL approach before starting activities due to their novelty in the ABSL approach. We also recommend starting the activities with sample activities to see students' responses and problems about the process and take necessary actions to prevent the problems in the actual implementation. As an effective approach for students' academic achievements, the ABSL approach can be used to enhance students' motivation and participation in classroom teachings. Finally, we recommend future studies to examine students' views about the ABSL approach and students' experiences in the implementation process by conducting process-oriented interviews before, during, and after research implementations.

\section{References}

Akkoyunlu, B., Altun, A., \& Y1lmaz-Soylu, M. (2008). Öğretim tasarımı (1. baskı). Ankara: Maya Akademi.

Akpınar, E., \& Ergin, Ö. (2005). The role of science teacher in constructivist theory. Illkögretim Online, 4(2), 55-64.

Albe, V. (2007). When scientific knowledge, daily life experience, epistemological and social considerations intersect: students"e argumentation in group discussions on a socioscientific issue. Research Science Education, 38, 67-90. doi: 10.1007/s11165-007-90402.

Alkın-Şahin, S., Tunca, N., \& Ulubey, Ö. (2014). The relationship between pre-service teachers' educational beliefs and their critical thinking tendencies. Elementary Education Online, 13(4), 1473-1492. doi: 10.17051/io.2014.56482.ft.

Altun, E. (2010). Teaching light unit to elementary school students' throught argumentation (Unpublished master's thesis). Gazi University, Ankara, Turkey.

Antiliou, A. (2012). The effect of an argumentation diagram on the self-evaluation of a creatıve solution (Doctoral dissertation). Retrieved from https://search.proquest.com/docview /1627759322?pq-origsite=summon (3674379).

Atılgan, H. (2017). Madde ve test istatistikleri. H. Atılgan (Ed.), Ĕ̈itimde ölçme ve değerlendirme içinde (10. baskı, ss. 259-280). Ankara: Anı Yayıncılık.

Aydoğdu, Z. (2017). Investigation of effects the argumentation based science teaching on the academic success, motivation, interest and attitudes towards science (Unpublished master's thesis). Sakarya University, Sakarya, Turkey. 
Balc1, M. (2015). Examining the effectiveness of argumentation based science teaching on 4th grade students (Unpublished doctoral dissertation). Dumlupınar University, Kütahya, Turkey.

Basso A.S. (2009). Using the science writing heuristic to enhance middle school science student's understanding of force and motion laboratory activities (Doctoral dissertation). Retrieved from https://search.proquest.com/docview/305179816?pq-origsite=summon (1466002).

Baştürk, S. (2014). Çoktan seçmeli testler. S. Baştürk (Ed.), Eğitimde ölçme ve değerlendirme içinde (1. bask1, ss. 119-154). Ankara: Nobel Yayıncılık.

Bell, P., \& Linn, M. C. (2000). Scientific arguments as learning artifacts: Designing for learning from the web with KIE. International Journal of Science Education, 22(8), 797-817. doi: $10.1080 / 095006900412284$.

Boyraz, D. S., Hacioğlu, Y., \& Aygün, M. (2016). Argumentation and concepts confusion: melting and dissolving. Gazi Üniversitesi Gazi Eğitim Fakültesi Dergisi, 36(2), 233-267.

Bozkurt, R. (2017). The effect of argumentation-based inquiry approach supported by upper cognitive activitie on science achievement of preservice science (Unpublished master's thesis). Kastamonu University, Kastamonu, Turkey.

Can, A. (2017). SPPS ile bilimsel araştırma sürecinde nicel veri analizi (5. Bask1). Ankara: Pegem Akademi.

Cartoon Pictures. Retrieved from https://www.freepik.com/free-vector/colorful-collectionwith-great-variety-of-avatars_1258263.htm\#term=face\&page $=1 \&$ position $=0$ http://osoq.com/caricatures/teacher-caricature.htm.

Cavlazoglu, B., \& Stuessy, C. (2017). Changes in science teachers' conceptions and connections of STEM concepts and earthquake engineering. The Journal of Educational Research, 110(3), 239-254.

Cavlazoglu, B., \& Stuessy, C. (2018). Examining science teachers' argumentation in a teacher workshop on earthquake engineering. Journal of Science Education and Technology, 27(4), 348-361.

Çetin, P. S., Erduran, S., \& Kaya, E. (2010). Understanding the nature of chemistry and argumentation: The case of pre-service chemistry teachers. Ahi Evran Üniversitesi Kırşehir Eğitim Fakültesi Dergisi, 11(4), 41-59.

Çetin, P. S., Kutluca, A. Y., \& Kaya, E. (2013). Öğrencilerin argümantasyon kalitelerinin incelenmesi. Fen Bilimleri Öğretimi Dergisi, 2(1), 56-66.

Ceylan, Ç. (2010). Implementing the science writing heuristic (swh) approach in science laboratory activities (Unpublished master's thesis). Gazi University, Ankara, Turkey.

Chin, C., \& Osborne, J. (2008). Students' questions: a potential resource for teaching and learning science. Studies in Science Education, 44(1), 1-39. doi: 10.1080/03057260701828101.

Chin, C., \& Osborne, J. (2010). Supporting Argumentation through students' questions: Case studies in science classrooms, Journal of the Learning Sciences, 19(2), 230-284. doi: 10.1080/10508400903530036. 
Çiftçi, A. (2016). Investigation of fifth, sixth and seventh grade students' argumentation quality in science lessons (Unpublished master's thesis). Muş Alparslan University, Muş, Turkey.

Çinici, A., Özden, M., Akgün, A., Herdem, K., Karabiber, L., \& Deniz, M. (2014). Investigating the effectiveness of argumentation based activities supported with concept cartoon. Adıyaman Üniversitesi Sosyal Bilimler Enstitüsü Dergisi, 7(18), 571-596. doi: http://dx.doi.org/10.14520/adyusbd.839.

Creswell, J. W. (2012). Educational research: Planning, conducting, and evaluating quantitative and qualitative research (4th ed.). Baston: Pearson

Creswell, J.W., \& Plano-Clark, V.L. (2007). Designing and conducting: Mixed methods research. Thousand Oaks, California: Sage Publication.

Crowell, A., \& Kuhn, D. (2012). Developing dialogic argumentation skills: A three-year intervention study. Journal of Cognition and Development, 15(2), 363-381. doi: 10.1080/15248372.2012.725187.

Dawson, V., \& Venville, G. J. (2009). High-school students' informal reasoning and argumentation about biotechnology: An indicator of scientific literacy. International Journal of Science Education, 31(11), 1421-1445. doi: 10.1080/09500690801992870.

Demir, F. B. (2017). The arguments of social studies teacher candidates' workbased training process, according to the determination of the level of argument (Unpublished master's thesis). Kastamonu University, Kastamonu, Turkey.

Demirel, O. E. (2014). Effects of problem based learning and argumentation based learning on the chemistry achievement mixtures unit, their science process skills and science reasoning aptitudes (Unpublished master's thesis). Mustafa Kemal University, Kastamonu, Turkey.

Demirel, R. (2016). Argümantasyon destekli öğretimin öğrencilerin kavramsal anlama ve tartışma istekliliklerine etkisi. Kastamonu Eğitim Dergisi, 24(3), 1087-1108.

Deniz, T. (2014). Use of socioscientific argumentation approach in the environmental education (Unpublished master's thesis). Gazi University, Ankara, Turkey.

Domaç, G. G. (2011). The effect of the argumentation - based learnings in terms socioscientific issues in biology education (Unpublished master's thesis). Gazi University, Ankara, Turkey.

Driver, R., Newton, P., \& Osborne, J. (2000). Establishing the norms of scientific argumentation in classrooms. Science Education, 84(3), 287-312. doi: 10.1002/(SICI)1098-237X(200005)84:3\%3C287::AID-SCE1\%3E3.0.CO;2-A.

Duran, M., Doruk, M., \& Kaplan, A. (2017). An examination of the effectiveness of argumentation-based probability teaching on middle school students' achievements and anxieties. Eğitimde Kuram ve Uygulama, 13(1), 55-87.

Duschl, R. A., \& Osborne, J. (2002). Supporting and promoting argumentation discourse in science education. Studies in Science Education, 38(1), 39-72. doi: 10.1080/03057260208560187. 
Eceyurt-Türk, G. (2017). The effect of argumentation-supported roblem based learning applications on the acid/ basesand gases success of pre-service science teachers (Unpublished doctoral dissertation). Gazi University, Ankara, Turkey.

Erduran, S., Simon, S., \& Osborne, J. (2004). TAPping into argumentation: Developments in the application of Toulmin's argument pattern for studying science discourse. Science Education, 88(6), 915-933. doi: 10.1002/sce.20012.

Fraenkel, J. R., Wallen, N. E., \& Hyun, H. H. (2012). How to design and evaluate research in education (8th ed.). New York: McGraw-Hill.

Green, S. B., \& Salkind, N. J. (2005). Using Spss for windows and macintosh: Analyzing and understanding data. Upper Saddle River, New Jersey 07458.

Greenbowe, T. J., Poock, J. R., Burke, K. A., \& Hand, B. M. (2007). Using the science writing heuristic in the general chemistry laboratory to improve students' academic performance. Journal of Chemical Education, 84(8), 1371-1379. doi: 10.1021/ed084p1371.

Güler, Ç. (2016). The effect of "argumentation based science learning approach" on academic success of science teacher candidates and their opinions about the approach (Unpublished master's thesis). Akdeniz University, Antalya, Turkey.

Gündüz, Ç. (2017). Developing argumentation based material for the learning of chemical equilibrium and micro world (Unpublished master's thesis). Recep Tayip Erdoğan University, Rize, Turkey.

Günel, M., Kabataş-Memiş, E., \& Büyükkasap, E. (2010). Effects of the science writing heuristic approach on primary school students' science achievement and attitude toward science course. Education and Science, 35(155), 49-62.

Hand, B., Prain, V., \& Wallace, C. (2002). Influences of writing tasks on students' answers to recall and higher-level test questions. Research in Science Education, 32(1), 19-34. doi: 10.1023/A:1015098605498.

Hand, B., Wallace, C., \& Yang, E. (2004). Using the science writing heuristic to enhance learning outcomes from laboratory activities in seventh grade science: Quantitative and Qualitative aspects. International Journal of Science Education, 26, 131-149. doi: $10.1080 / 0950069032000070252$.

Hasançebi, F. (2014). The impacts of argumentat based inquiry approach on students' science achievements, argument skill and personal development (Unpublished doctoral dissertation). Atatürk University, Erzurum, Turkey.

Hohenshell, L. M., \& Hand, B. (2006). Writing-to-learn strategies in secondary school cell biology: A mixed method study. International Journal of Science Education, 28(2-3), 261-289. doi: 10.1080/09500690500336965.

Jan, M. (2009). Designing an augmented reality game-based curriculum for argumentation (Doctoral dissertation). Retrieved from https://search.proquest.com/docview/ 305034117?pq-origsite $=$ summon (3384520).

Jimenez-Aleixandre, M.P., \& Erduran, S. (2007). Argumentation in science education: an overview. S. Erduran \& M. P. Jimenez-Aleixandre (Eds.), Argumentation in science education: perspectives from classroom-based research (pp. 3-27). Springer. 
Jimenez-Aleixandre, M.P., Rodriguz, A. B., \& Duschl, R. A. (2000). "Doing the lesson" or "doing science": Argument in high school genetics. Science Education, 88(6), 757-792. doi: 10.1002/1098-237X(200011)84:6\%3C757::AID-SCE5\%3E3.0.CO;2-F.

Kabataş-Memiş, E. (2011). Effects of the argumentation based science learning approach and self-evaluation on primary school students' science and technology course achievement and retention of the achievement (Unpublished doctoral dissertation). Atatürk University, Erzurum, Turkey.

Kabataş-Memiş, E. (2014). Elementary students' ideas about on implementation of argumentation based science learning approach. Kastamonu Eğitim Dergisi, 22(2), 401418.

Kan, A. (2017). Ölçme aracı geliştirme. S. Tekindal (Ed.), Ĕ̈itimde ölçme ve değerlendirme içinde (5. baskı, ss. 241-277). Ankara: Pegem A Yayıncılık.

Kana, F. (2013). A mixed-embedded experimental research on the practice of argumentationbased language teaching in pre-service (Unpublished doctoral dissertation). Onsekiz Mart University, Çanakkale, Turkey.

Karaatlı, M. (2017). Verilerin düzenlenmesi ve gösterimi. Ş. Kalaycı (Ed.), SPSS uygulamalı çok değişkenli istatistik teknikleri içinde (8. bask1, ss. 3-47). Ankara: Dinamik Akademi

Karaca, E. (2016). Test ve madde analizi. M. Gömleksiz \& S. Erkan (Ed.), Ĕ̈itimde ölçme ve değerlendirme içinde (4. baskı, ss. 239-306). Ankara: Nobel Yayıncılık.

Kaya, O. N., \& Kılıç, Z. (2008). Argumentative discourse for the effective teaching of science. Ahi Evran Üniversitesi Kırşehir Eğitim Fakültesi Dergisi, 9(3), 89-100.

Keys, C. W., Hand, B., Prain, V., \& Collins, S. (1999). Using the science writing heuristic as a tool for learning from laboratory investigations in secondary science. Journal of Research in Science Teaching, 36(10), 1065-1084.

Kıngir, S. (2011). Using the science writing heuristic approach to promote student understanding in chemical changes and mixtures (Unpublished doctoral dissertation). Middle East Technical University, Ankara, Turkey.

Kıngir, S., Geban, Ö., \& Günel, M. (2011). Students' ideas about the implementation of the argumentation based science inquiry approach in their chemistry course. Ahmet Keleş Ĕ̈itim Fakültesi Dergisi, 32, 15-28.

Knight, A. M., \& McNeill, K. L. (2015). Comparing students' 1ndividual written and collaborative oral socioscientific arguments. International Journal of Environmental \& Science Education, 10(5), 623-647. doi: 10.12973/ijese.2015.258a.

Kolsto, S. D. (2006). Patterns in students ${ }^{\text {ee }}$ argumentation confronted with a risk-focused socioscientific issue. International Journal of Science Education, 28(14), 1689-1716. doi:10.1080/09500690600560878.

Kuhn, D., Wang, Y., \& Li, H. (2010). Why argue? Developing understanding of the purposes and values of argumentive discourse, Discourse Processes, 48(1), 26-49. doi: $10.1080 / 01638531003653344$. 
Kunsch, D. W., Schnarr, K., \& van Tyle, R. (2014). The use of argument mapping to enhance critical thinking skills in business education. Journal of Education for Business, 89(8), 403-410. doi:10.1080/08832323.2014.925416.

Kutluca, A. Y. (2016). The investigation of the relationship between pre-service science teachers' quality of sociosclentific argumentation and their the nature of science understanding (Unpublished doctoral dissertation). Kastamonu University, Kastamonu, Turkey.

Larson, A. A., Britt, M. A., \& Kurby, C. A. (2009). Improving studentse evaluation of informal arguments. The Journal of Experimental Education.77(4), 339-365. doi: 10.3200/JEXE.77.4.339-366.

Lawson, A. E. (2003). The nature and development of hypothetico-predictive argumentation with implications for science teaching. International Journal of Science Education, 25(11), 1387-1408. doi: /10.1080/0950069032000052117.

Lu, J., \& Zhang, Z. (2013). Assessing and supporting argumentation with online rubrics. International Education Studies, 6(7), 66-77. doi:10.5539/ies.v6n7p66

McMillan, J. H. \& Schumacher, S. (2014). Research in education: Evidence-based inquiry (7th ed.). London: Pearson.

Miles, M. B., \& Huberman, A. M. (2016). Nitel veri analizi (S. Akbaba, A. A. Ersoy, çev. ed.). Ankara: Pegem Ankara.

Mirza, N. M., \& Perret-Clermont, A. N. (2009). Argumentation and education theoretical foundations and practices, London: Springer.

Monte-Sano, C. (2012). What makes a good history essay? Assessing historical aspects of argumentative writing. Social Education. 76(6), 294-298.

Nam, J., Choi, A., \& Hand, B. (2011). Implementation of the science writing heuristic (swh) approach in 8th grade science classrooms. International Journal of Science and Mathematics Education, 9(5),1111-1133. doi: 10.1007/s10763-010-9250-3.

Namdar, B., \& Tuskan, İ. B. (2018). Science teachers' views of scientific argumentation. Hacettepe Üniversitesi Eğitim Fakültesi Dergisi, 33(1), 1-22. doi: 10.16986/HUJE.2017030137.

Nussbaum, E. M. (2002). Scaffolding argumentation in the social studies classroom. The Social Studies, 93(2) 79-83. doi: https://doi.org/10.1080/00377990209599887

Nussbaum, E. M. (2008). Using argumentation Vee diagrams (AVDs) for promoting argument counterargument integration in reflective writing. Journal of Educational Psychology, 100(3), 549- 565. doi: 10.1037/0022-0663.100.3.549.

Nussbaum, E. M., \& Sinatra, G. M. (2003). Argument and conceptual engagement. Contemporary Educational Psychology, 28(3), 384-395. doi:10.1016/S0361-476X(02)00038-3.

Nussbaum, E. M., Winsor, D. L., Aqui, Y. M., \& Poliquin, A. M. (2007). Putting the pieces together: Online argumentation Vee diagrams enhance thinking during discussions. International Journal of Computer Supported Collaborative Learning, 2, 479-500. doi: 10.1007/s11412-007-9025-1. 
Ocak, M. A. (2011). Öğretim tasarımı modelleri. M. A. Ocak (Ed.), Öğretim tasarımı: Kuramlar, modeller ve uygulamalar içinde (2. bask1, ss. 30-267). Ankara: Anı Yayıncılık.

Öğreten, B. (2014). The effects of argumentation based instruction process on academic achievement and argumentation levels (Unpublished master's thesis). Amasya University, Amasya, Turkey.

Oğuz-Haçat, S., \& Demir, F.B. (2016). Evaluation by toulmin argument model of social studies curriculum and textbooks. Abant İzzet Baysal Üniversitesi Eğitim Fakültesi Dergisi, 16, 1572-1602.

Okumuş, S. (2012). The effects of argumentation model on students' achievement and understanding level on the unit of "states of matter and heat" (Unpublished master's thesis). Karadeniz Teknik University, Trabzon, Turkey.

Okumus, S., \& Ünal, S. (2012). The effects of argumentation model on students' achievement and argumentation skills in science. Procedia-Social and Behavioral Sciences, 46, 457461. doi: 10.1016/j.sbspro.2012.05.141.

Ortega, F.J.R., Alzate, O.E.T., \& Bargallo, C.M. (2015). A model for teaching argumentation in science class. Educ. Pesqui. Sao Paulo, 41(3), 629-643. doi: 10.1590/S15179702201507129480 .

Osborne, J., Erduran, S., \& Simon, S. (2004a). Enhancing the quality of argumentation in school science. Journal of Research in Science Teaching, 41(10), 994-1020. doi 10.1002/tea.20035.

Osborne, J., Erduran, S., \& Simon, S. (2004b). Ideas, evidence and argument in science: Cpd training pack. London: King's College.

Özcan, R., Aktamış, H., \& Hiğde, E. (2018). Computational thinking and integrative education (steam) in science education. Pamukkale Üniversitesi Ĕ̈itim Fakültesi Dergisi, 43, 93106. doi: 10.9779/PUJE857.

Öztürk, A. (2013). An action research about argumentation skill on socio scientific issues and development of attitudes towards human rights (Unpublished doctoral dissertation). Çukurova University, Adana, Turkey.

Pallant, J. (2005). SPSS survival manual: A step by guide to data analysis using SPSS for windows (2nd ed.). National Library of Australia.

Polat, H. (2014). The effect of the argumentation method 7th grade elementary school in the structure of atom upon the student success (Unpublished master's thesis). İnönü University, Malatya, Turkey.

Poock, J. R. (2005). Investigating the effectiveness of implementing the science writing heuristic on student performance in general chemistry (Doctoral dissertation). Retrieved from https://lib.dr.iastate.edu/cgi/viewcontent.cgi?article=2848\&context=rtd.

Sadler, T.D., \& Fowler, S.R. (2006). A threshold model of content knowledge transfer for socio scientific argumentation. Science Education, 90(6) 986-1004. doi: 10.1002/sce.20165

Şahin, E. (2016). The effect of argumentation based science learning approach on academic success, metacognition and critical thinking skills of gifted students (Unpublished doctoral dissertation). Gazi University, Ankara, Turkey. 
Sampson, V., \& Gleim, L. (2009). Argument-driven inquiry to promote the understanding of important concepts \& practices in biology. The American Biology Teacher, 71(8), 465472. doi: $10.2307 / 20565359$.

Şekerci, A. R. (2013). The effect of argumentation based instruction on students' argumentation skills and conceptual understanding in chemistry laboratory (Unpublished doctoral dissertation). Atatürk University, Erzurum, Turkey.

Şimşek, A. (2009). Öğretim tasarımı (1. baskı). Ankara: Nobel Yayıncılık.

Swartz, R. J. (2008). Teaching students how to analyze and evaluate arguments in history. The Social Studies, 99(5), 208-216. doi:10.3200/TSSS.99.5.208-216 .

Tabachnick, B. G., \& Fidell, L. S. (2015). Çok değişkenli istatistiklerin kullanımı (M. Baloğlu, çev. ed.). Ankara: Nobel.

Tekeli, A. (2009). The effect of an argumentation-centered class environment on the conceptual change about acid base and the understanding nature of science (Unpublished master's thesis). Gazi University, Ankara, Turkey.

Tezci, E., \& Perkmen, S. (2013). Oluşturmacı perspektiften teknolojinin öğrenme-öğretme sürecine entegrasyonu. K. Çağıltay \& Y. Göktaş (Ed.), Öğretim teknolojilerinin temelleri: Teoriler, araştırmalar, eğilimler içinde (2. Bask1, ss. 193-217). Ankara: Pegem Akademi Yayınc1lik.

Tippett, C. (2009). Argumentation: The language of science. Journal of Elementary Science Education, 21(1), 17-25. doi:10.1007/BF03174713.

Torun, F. (2015). The relationship level between argumentation-based teaching and decisionmaking skills in social studies course (Unpublished doctoral dissertation). Gazi University, Ankara, Turkey.

Tümay, H., \& Köseoğlu, F. (2010). Promoting pre-service chemistry teachers' understanding of nature of science with argumentation focused activities in science. Gazi Eğitim Fakültesi Dergisi, 30(3), 859-876.

Türkoguz, S., \& Cin, M. (2013). Effects of argumentation based concept cartoon activities on students' conceptual understanding levels. Buca Eğitim Fakültesi Dergisi 35, 155-173.

Ulu, C., \& Bayram, H. (2015). Effects of laboratory activities through the argumentation based inquiry approach on 7th grade students' conceptual learning electricity in our daily life unit. Pamukkale Üniversitesi Eğitim Fakültesi Dergisi, 37, 63-77. doi: 10.9779/PUJE664.

Uluay, G. (2012). Investigation of the effect of scientific argumentation based teaching on student's success in teaching primary school 7th grade science and technology course force and motion unit teaching (Unpublished master's thesis). Kastamonu University, Kastamonu, Turkey.

Uluçınar-Sağır, Ş., \& Kılıç, Z. (2013). The effect of argumentation based teaching on the understanding levels of primary school students about the nature of science. Hacettepe Üniversitesi Eğitim Fakültesi Dergisi, 44, 308-318.

Untereiner, B. (2013). Teaching and learning the elements of argumentation (MSc thesis). https://dspace.library.uvic.ca/bitstream/handle/1828/4654/Untereiner_Brian_MA_2013.p $\mathrm{df}$ ?sequence $=1 \&$ is Allowed $=\mathrm{y}$. 
Von Aufschnaiter, C., Erduran, S., Osborne, J., \& Simon, S. (2008). Arguing to learn and learning to argue: Case studies of how student's argumentation relates to their scientific knowledge. Journal of Research in Science Teaching, 45(1), 101-131. doi: https://doi.org/10.1002/tea.20213.

Weng, W. Y., Lin, Y. R., \& She, H. C. (2017). Scaffolding for argumentation in hypothetical and theoretical biology concepts. International Journal of Science Education, 39(7), 877897. doi: 10.1080/ 09500693.2017.1310409.

Wissinger, D. R. (2012). Using argumentative discussions to enhance the written arguments of middle school students in social studies classrooms (Doctoral dissertation). Retrieved from https://search.proquest.com/docview/1175951070?pq-origsite=summon (3543618).

Yalçın-Çelik, A. (2010). An analysis of the influences of the teaching approach based on scientific argumentation on high school students' conceptual understanding, attitudes, and willingness for argumentation and the quality of argumentation (Unpublished doctoral dissertation). Gazi University, Ankara, Turkey.

Yeşildağ-Hasançebi, F., \& Günel, M. (2013). Effects of argumentation based inquiry approach on disadvantaged students' science achievement. Elementary Education Online 12(4), 1056- 1073.

Yeşiloğlu, S. N. (2007). Teaching gases topic to high school students through argumentation (Unpublished master's thesis). Gazi University, Ankara, Turkey.

Yore, L. D. (2000). Enhancing science literacy for all students with embed reading instruction and writing to learn activities. Journal of Deaf Studies and Deaf Education, 5(1), 105122. doi: $10.1093 /$ deafed/5.1.105.

Zohar, A., \& Nemet, F. (2002). Fostering students' knowledge and argumentation skills through dilemmas in human genetics. Journal of Research in Science Teaching, 39(1), 35-62. doi: 10.1002/tea. 10008 .

\section{Biographical Statements}

Yavuz AKBAŞ is associate professor at the Department of Turkish and Social Sciences Education in Faculty of Fatih Education at Trabzon University. He focus on social studies teaching, geography teaching, teacher training, concept teaching, spatial thinking skills, and argumentation.

İbrahim Fevzi ŞAHİN is professor at the Department of Turkish and Social Sciences Education in Faculty of Kazım Karabekir Education at Atatürk University. He focus on human geography, geography education, social studies teaching, argumentation and technology in social sciences.

Elif MERAL is assistant professor at the Department of Turkish and Social Sciences Education in Faculty of Kazım Karabekir Education at Atatürk University. She focus on social studies teaching, argumentation and technology in social sciences. 